\title{
Mitochondrial Cholesterol Loading Exacerbates Amyloid $\beta$ Peptide-Induced Inflammation and Neurotoxicity
}

\author{
Anna Fernández, ${ }^{1,2,3,4}$ Laura Llacuna, ${ }^{1,2,3,4}$ José C. Fernández-Checa, ${ }^{1,2,3,4 *}$ and Anna Colell ${ }^{1,2,3,4 *}$ \\ ${ }^{1}$ Department of Cell Death and Proliferation, Institut d'Investigacions Biomèdiques de Barcelona, Consejo Superior de Investigaciones Científicas and \\ Unidad de Hepatología, Hospital Clinic i Provincial, ${ }^{2}$ Centro de Investigaciones Biomédicas Esther Koplowitz, ${ }^{3}$ Centro de Investigación Biomédica en Red \\ de Enfermedades Hepáticas y Digestivas, and ${ }^{4}$ Institut d’Investigacions Biomèdiques August Pi i Sunyer, 08036 Barcelona, Spain
}

The role of cholesterol in Alzheimer's disease (AD) has been linked to the generation of toxic amyloid $\beta$ peptides (A $\beta$ ). Using genetic mouse models of cholesterol loading, we examined whether mitochondrial cholesterol regulates $\mathrm{A} \beta$ neurotoxicity and AD pathology. Isolated mitochondria from brain or cortical neurons of transgenic mice overexpressing SREBP-2 (sterol regulatory element binding protein 2) or NPC1 (Niemann-Pick type C1) knock-out mice exhibited mitochondrial cholesterol accumulation, mitochondrial glutathione (mGSH) depletion and increased susceptibility to A $\beta 1-42$-induced oxidative stress and release of apoptogenic proteins. Similar findings were observed in pharmacologically GSH-restricted rat brain mitochondria, while selective mGSH depletion sensitized human neuronal and glial cell lines to A $\beta 1-42$-mediated cell death. Intracerebroventricular human A $\beta$ delivery colocalized with mitochondria resulting in oxidative stress, neuroinflammation and neuronal damage that were enhanced in Tg-SREBP-2 mice and prevented upon mGSH recovery by GSH ethyl ester coinfusion, with a similar protection observed by intraperitoneal administration of GSH ethyl ester. Finally, APP/PS1 (amyloid precursor protein/presenilin 1) mice, a transgenic AD mouse model, exhibited mitochondrial cholesterol loading and mGSH depletion. Thus, mitochondrial cholesterol accumulation emerges as a novel pathogenic factor in AD by modulating $\mathrm{A} \beta$ toxicity via mGSH regulation; strategies boosting the particular pool of $\mathrm{mGSH}$ may be of relevance to slow down disease progression.

\section{Introduction}

Alzheimer's disease $(\mathrm{AD})$ is a major neurodegenerative disorder characterized by progressive memory loss and cognitive impairment due to neuronal death mainly in cortex and hippocampus (Mattson, 2004; Zlokovic, 2005; Selkoe, 2007). Given the lack of effective therapy and its association with aging, $\mathrm{AD}$ is one of the most pressing health challenges worldwide. Although AD pathogenesis is still unknown, accumulation or faulty brain clearance of neurotoxic amyloid $\beta$ peptides $(\mathrm{A} \beta)$ is thought to play a key role in AD (Tanzi et al., 2004; Walsh and Selkoe, 2004; Deane and Zlokovic, 2007; Haass and Selkoe, 2007). Indeed, recent data have

Received 0ct. 12, 2008; revised Feb. 5, 2009; accepted March 19, 2009.

This work was supported in part by the Plan Nacional de Investigación Científica, Desarrollo e Innovación Tecnológica Grants SAF2005-03923 and SAF2006-06780, by Research Center for Liver and Pancreatic Diseases Grant P50 AA 11999 funded by the National Institute on Alcohol Abuse and Alcoholism, and by the Centro de Investigación Biomédica en Red de Enfermedades Hepáticas y Digestivas supported by the Instituto de Salud Carlos III. We are grateful to Dr. M. Guzman from Complutense University, Madrid, for kindly providing the glia-derived cell lines. The technical assistance of Alberto García-Martínez is highly appreciated. We thank the Servicio Científico-técnico of Institut d'Investigacions Biomèdiques August Pi i Sunyer for EM, confocal imaging, and flow cytometry analysis assistance, Dr. C. Sanmartin from Navarra University for the HP synthesis, and Dr. S. Pons for kindly advising on neuron cultures. We thank Drs. C. Garcia-Ruiz, M. Mari, and A. Morales for critical reading of this manuscript. A.C. is supported by the Ramon y Cajal Research Program (Ministerio de Educación y Ciencias). This work is dedicated to patients suffering from Alzheimer's disease, in particular Faustina Torres Muñoz, who recently passed away as a victim of this devastating disease.

*Anna Colell and José C. Fernández-Checa share senior authorship.

Correspondence should be addressed to either Anna Colell or Jose C. Fernández-Checa, Department of Cell Death and Proliferation, Institut d'Investigacions Biomèdiques de Barcelona, Rosselló 161,08036 Barcelona, Spain, E-mail: anna.colell@iibb.csic.es or checa229@yahoo.com.

D01:10.1523/JNEUROSCI.4909-08.2009

Copyright $\odot 2009$ Society for Neuroscience $\quad 0270-6474 / 09 / 296394-12 \$ 15.00 / 0$ showed that $\mathrm{A} \beta$ dimers isolated directly from $\mathrm{AD}$ brains impair synaptic plasticity and memory (Shankar et al., 2008).

In addition to aging, epidemiological observations identified hypercholesterolemia in mid-life as a major risk factor for $\mathrm{AD}$ (Notkola et al., 1998; Wolozin et al., 2000; Anstey et al., 2008). Despite that studies examining statin usage have produced mixed conclusions, the epidemiological evidence linking cholesterol to $\mathrm{AD}$ has been supported by in vivo (Schönknecht et al., 2002; Bandaru et al., 2007) and in vitro studies (Fassbender et al., 2001; Kalvodova et al., 2005; Osenkowski et al., 2008), indicating that membrane cholesterol promotes the amyloidogenic processing of the membrane bound amyloid precursor protein (APP) by the $\beta$-secretase BACE1 ( $\beta$-site APP-cleaving enzyme 1$)$ and $\gamma$-secretase to generate toxic $\mathrm{A} \beta$.

Well before plaques are observed, intracellular aggregates of $\mathrm{A} \beta$ develop early in $\mathrm{AD}$ transgenic mice, which congregate in synaptic compartments and correlate with cognitive impairment (Oddo et al., 2003). Current evidence indicates the targeting of $\mathrm{A} \beta$ to intracellular sites, most notably mitochondria, causing oxidative stress, mitochondrial dysfunction and cell death (Casley et al., 2002; Lustbader et al., 2004; Caspersen et al., 2005; Lin and Beal, 2006; Manczak et al., 2006).

Mitochondria do not synthesize glutathione (GSH) de novo and mitochondrial GSH (mGSH) originates by the transport of cytosol GSH into mitochondria by a specific carrier whose sensitivity to changes in membrane fluidity has been previously characterized (for review, see Fernandez-Checa and Kaplowitz, 2005). Cholesterol-mediated changes in membrane dynamics impairs the mitochondrial transport of GSH, resulting in the depletion of 
mGSH, a critical antioxidant defense that determines the susceptibility to stimuli that induce mitochondrial oxidative stress, such as TNF- $\alpha$, Fas, or hypoxia (Colell et al., 1997; Marí et al., 2006, 2008; Lluis et al., 2007). However, the specific role of $\mathrm{mGSH}$ in the regulation of $\mathrm{A} \beta$ toxicity has not been previously described. Thus, we addressed whether mitochondrial cholesterol accumulation modulates $\mathrm{A} \beta$ neurotoxicity and $\mathrm{AD}$ pathology, using genetic models of cholesterol loading, namely, transgenic mice overexpressing SREBP-2 and NPC1 ${ }^{-1-}$ mice (Yu et al., 2005). Overall, these findings expand the role of cholesterol in $\mathrm{AD}$, indicating that in addition to fostering $\mathrm{A} \beta$ production, mitochondrial cholesterol loading determines $\mathrm{A} \beta$ neurotoxicity and $\mathrm{AD}$ like pathology via mGSH depletion. Although total GSH depletion and altered GSH redox cycle have been described in AD (Boyd-Kimball et al., 2005; Resende et al., 2008), the fact that the pool of mGSH rather than cytosol GSH determines A $\beta$ susceptibility implies that efforts should be directed to specifically replenish $\mathrm{mGSH}$ to slow down disease progression, using strategies that bypass the block of GSH transport into mitochondria imposed by cholesterol deposition.

\section{Materials and Methods}

Tg-SREBP-2, NPC1 ${ }^{-1-}$ and Tg-APP/PS1 mice. Breeding pairs of B6;SJL$\mathrm{Tg}(\mathrm{rPEPCKSREBF} 2) 788 \mathrm{Reh} / \mathrm{J}, \mathrm{BALB} / \mathrm{cJ} \quad \mathrm{NPC1}^{\mathrm{NIH}}$ and B6C3$\mathrm{Tg}$ (APPswe,PSEN1dE9)85Dbo/J mice were obtained from The Jackson Laboratory. At the time of weaning ( $21 \mathrm{~d}$ ), mice were genetically identified by PCR using DNA prepared from tail-tips and following the genotyping protocols provided by the supplier. All procedures involving animals and their care were approved by the ethics committee of the University of Barcelona and were conducted in accordance with institutional guidelines in compliance with national and international laws and policies.

Cell cultures. SH-SY5Y human neuroblastoma (ECACC) and C6 rat glioma cell lines were grown in Ham's F12 (Sigma) containing 10\% FBS and $2 \mathrm{~mm}$ glutamine. U118 human glioma and neuroglioma $\mathrm{H} 4$ cell lines were maintained in DMEM medium (Invitrogen) supplemented with $10 \%$ FBS and $2 \mathrm{~mm}$ glutamine. Mice neuron-rich cultures were obtained from the cerebral cortex of embryos (day 16) using standard techniques. Dissociated cells were suspended in Neurobasal medium (Invitrogen) with $2.5 \%(\mathrm{v} / \mathrm{v})$ B27 supplement (Invitrogen), $0.5 \mathrm{~mm}$ glutamine, and $10 \%$ FBS and plated onto poly-D-lysine coated plates at a cell density of $2 \times 10^{5} / \mathrm{cm}^{2}$. The culture medium was changed $3 \mathrm{~h}$ after plating and every other day thereafter. After $24 \mathrm{~h}$ in vitro, the culture medium was replaced with serum-free medium. Experiments were performed at $6 \mathrm{~d}$ in vitro (DIV). The cellular composition of the cultures was evaluated at this time by immunohistochemical analysis using antibodies to neuron- and glial-specific markers and was found to consist of $>95 \%$ neurons.

Mitochondrial isolation. Cerebral cortices were isolated and homogenized in $210 \mathrm{~mm}$ Mannitol, $60 \mathrm{~mm}$ Sucrose, $10 \mathrm{~mm} \mathrm{KCl,} 10 \mathrm{~mm}$ Sodium succinate, $1 \mathrm{~mm}$ ADP, 0.25 mм DTT, 0.1 mm EGTA, 10 mм HEPES, pH 7.4. The homogenates were centrifuged at $600 \times g$ for $10 \mathrm{~min}$, with the resulting supernatant being centrifuged at $10,300 \times g$ for $15 \mathrm{~min}$. The resulting pellet was suspended in $2 \mathrm{ml}$, loaded onto $8 \mathrm{ml}$ of $30 \%(\mathrm{v} / \mathrm{v})$ Percoll gradient and centrifuged at 95,000 $\times \mathrm{g}$ for $30 \mathrm{~min}$. The mitochondrial pellet was then rinsed twice by centrifuging $15 \mathrm{~min}$ at $7000 \times \mathrm{g}$. Cortical neurons were fractionated into cytosol and mitochondria by digitonin permeabilization followed by oil gradient centrifugation as described previously in detail (Fernandez-Checa et al., 1987).

GSH and cholesterol measurements. GSH levels in homogenates or cytosol and mitochondria were analyzed by the recycling method (Tietze, 1969). For total cholesterol determination, $10 \mathrm{mg}$ of protein was saponified with alcoholic $\mathrm{KOH}$ in a $60^{\circ} \mathrm{C}$ heating block for $30 \mathrm{~min}$. After the mixture had cooled, $10 \mathrm{ml}$ of hexane and $3 \mathrm{ml}$ of distilled water were added and shaken to ensure complete mixing. Appropriate aliquots of the hexane layer were evaporated under nitrogen and used for cholesterol measurement. HPLC analysis was made using a Waters $\mu$ Bondapak C18 $10 \mu \mathrm{m}$ reversed-phase column $(30 \mathrm{~cm} \times 4 \mathrm{~mm}$ inner diameter $)$, with the mobile phase being 2-propanol/acetonitrile (50:50, v/v) and the flow rate of $1 \mathrm{ml} / \mathrm{min}$. The amount of cholesterol was calculated from standard curves and the identity of the peaks was confirmed by spiking the sample with known standards.

Preparation of $A \beta$ peptides. Human recombinant $\mathrm{A} \beta 1-42$ and $\mathrm{A} \beta 42-1$ peptides (Bachem) were dissolved to $1 \mathrm{~mm}$ in hexafluoroisopropanol (HFIP) and aliquoted into microcentrifuge tubes, then the HFIP was evaporated, and the peptides were stored at $20^{\circ} \mathrm{C}$ until use. For oligomeric assembly, concentrated peptides were resuspended in DMSO (5 $\mathrm{mm}$ ) and then diluted to $100 \mu \mathrm{M}$ in phenol red-free media and incubated at $4^{\circ} \mathrm{C}$ for $24 \mathrm{~h}$. Western blot analysis demonstrated the presence of soluble oligomeric forms of $\mathrm{A} \beta$ (supplemental Fig. S1, available at www.jneurosci.org as supplemental material).

$A \beta$ infusion. The infusion model was adopted from previous work on the rat infusion model (Frautschy et al., 1996). Briefly, stainless steel cannula attached to micro-osmotic pumps (model 1004, Alzet) were stereotaxically implanted into the right lateral cerebral ventricle (at coordinates $-1.0 \mathrm{~mm}$ mediolateral and $-0.5 \mathrm{~mm}$ anterioposterior from bregma; $-2 \mathrm{~mm}$ dorsal-ventral from skull). Pumps contained either oligomeric human $\mathrm{A} \beta 1-42(0.45 \mu \mathrm{g} / \mu \mathrm{l})$ in vehicle [4 mм HEPES pH 8.0 $+0.21 \mu \mathrm{g} / \mu \mathrm{l}$ human high-density lipoprotein (HDL)] or vehicle alone. HDL was used in the pump to reduce $A \beta$ aggregation and enhance neuropil delivery. The pump contents were released over a period of $28 \mathrm{~d}$ at a rate of $\sim 0.11 \mu \mathrm{l} / \mathrm{h}(50 \mathrm{ng} / \mathrm{h} \mathrm{A} \beta ; 26 \mathrm{ng} / \mathrm{h} \mathrm{HDL})$, which corresponds to 36 $\mathrm{pmol} / \mathrm{g}$ brain/h. ELISA analyses indicated that the human recombinant $\mathrm{A} \beta$ content found in the brain after this infusion period was $4.3 \pm 0.6$ $\mathrm{ng} / \mathrm{g}$, which is in the range of the levels found in transgenic mice and humans (Hsiao et al., 1996; Pirttilä et al., 1997). At postoperative day 28, mice were anesthetized and perfused with PBS buffer containing a protease inhibitor cocktail. The brains were then removed and longitudinally bisected. The right half of the brain was fixed and embedded for histological examination, while the left hemisphere was snap frozen for biochemical evaluation. Levels of endogenous or human recombinant A $\beta 1-42$ peptide in brain extracts were determined with duplicate measurements by the $\mathrm{A} \beta 1-42$ ELISA kits from Biosource International, according to the manufacturer's instructions. In some cases, GSH ethyl ester was either added to the infusion solution $(0.5 \mathrm{mmol} / \mathrm{ml})$ as described previously (Zeevalk et al., 2007), or injected intraperitoneally $(1.25 \mathrm{mmol} / \mathrm{kg} / \mathrm{d})$ every $12 \mathrm{~h}$ over the last 2 weeks of the infusion period as described previously (Mårtensson et al., 1993) to test its efficacy in the protection against $\mathrm{A} \beta$-mediated neuroinflammation and injury.

Immunohistochemistry. Cryopreserved sections $(10 \mu \mathrm{m})$ from -1.2 $\mathrm{mm}$ through $-2.4 \mathrm{~mm}$ from bregma were processed according to the avidin-biotin-peroxidase (ABC, Vectastain; Vector Laboratories) staining method. After antigen retrieval treatment, the endogenous peroxidase was blocked by exposure to $2 \% \mathrm{H}_{2} \mathrm{O}_{2}$ in methanol for $30 \mathrm{~min}$. The sections were treated with the Avidin/Biotin blocking kit from Vector Laboratories according to the manufacturer's instructions. The primary antibodies: mouse anti-A $\beta$ (1:300, Sigma), rabbit anti-GFAP (1:500, Dako), and rat anti-F4/80 (1:200, Santa Cruz Biotechnology) were incubated overnight at $4^{\circ} \mathrm{C}$. After washing with PBS, sections were then incubated for $1 \mathrm{~h}$ with appropriated biotinylated secondary antibodies at a dilution of 1:400, followed by ABC staining for $1 \mathrm{~h}$. The immunoreaction was visualized with diaminobenzidine (DAB enhanced liquid substrate system, Sigma). Sections were counterstained with hematoxylin (Dako).

Immunofluorescence and laser confocal imaging. Cortical neurons were fixed for 15 min with $3.7 \%$ paraformaldehyde before permeabilization with $0.1 \%$ saponin in blocking buffer ( $1 \%$ BSA $+20 \mathrm{~mm}$ Glycine in PBS) for $15 \mathrm{~min}$. Then, cells were incubated in the presence of anticytochrome $c$ monoclonal antibody (1:200, clone 6H2.B4; PharMingen) diluted in blocking buffer with $0.025 \%$ saponin for $1 \mathrm{~h}$ at $37^{\circ} \mathrm{C}$ after 45 min incubation with the secondary antibody, FITC-conjugated goat anti-mouse IgG (1:400, Caltag Laboratories). Filipin ( $50 \mathrm{mg} / \mathrm{ml}$, Sigma) was added during the secondary antibody incubation. Dewaxed hippocampal sections were first boiled in citrate buffer $(10 \mathrm{~mm}$ sodium citrate $\mathrm{pH}$ 6.0) and incubated with $0.1 \mathrm{M}$ glycine/PBS for $20 \mathrm{~min}$ to reduce autofluorescence. Tissues processed for $\mathrm{A} \beta$ staining were pretreated with $99 \%$ formic acid for $7 \mathrm{~min}$. The sections were incubated overnight at $4^{\circ} \mathrm{C}$ with monoclonal anti-A $\beta 1-42$ (1:300, Sigma) rabbit anti-cytochrome $c$ 
(1:100, Santa Cruz Biotech), rat anti-F4/80 (1:200, Santa Cruz Biotechnology), and rabbit anti-GFAP (1:500, Dako) antibodies diluted in antibody diluent with background-reducing components from Dako. After washing in PBS, the sections were incubated for $45 \mathrm{~min}$ with the secondary antibodies diluted in the same vehicle solution. The secondary antibodies used were: FITC-conjugated goat anti-mouse IgG (1:400, Caltag Laboratories), Cy3-conjugated anti-rabbit IgG (1:400, Jackson ImmunoResearch), and Cy3-conjugated anti-rat IgG (1:400, Jackson ImmunoResearch). In some cases, nuclei were stained with Hoechst 33258 (2 $\mu \mathrm{g} / \mathrm{ml}$ ) before mounting the samples in Fluoromount-G (Southern Biotechnology). Confocal images were collected using a Leica SP2 laser scanning confocal microscope equipped with UV excitation, an argon laser, a 633/1.32 OIL PH3 CS objective and a confocal pinhole set at 1 Airy unit. All the confocal images shown were single optical sections.

Caspase-3 activity and mitochondrial membrane potential $(\Delta \Psi \mathrm{\Psi})$. Caspase activation in cell extracts was determined spectrofluorometrically using the specific fluorescent substrate Ac-DEVD-AMC $(100 \mu \mathrm{M}$, Bachem). The release of 7-amino-4-trifluoromethyl coumarin (AMC) was continuously recorded with excitation at $355 \mathrm{~nm}$ and emission at 460 $\mathrm{nm}$. The mitochondrial membrane potential was measured using tetramethylrhodamine ethyl ester (TMRE, $50 \mathrm{~nm}$ ). The dye retention was analyzed with a Becton-Dickinson FACScan flow cytometer in FL2.

Electron microscopy. Pellets containing the mitochondria purified fraction were fixed in $3 \%$ glutaraldehyde, $10 \mathrm{~mm}$ sodium phosphate buffer, $\mathrm{pH} 7.2$, postfixed in $1 \%$ osmium tetroxide, dehydrated in graded steps of ethanol through propylene oxide, and embedded in Spurr (Sigma). Finally, ultrathin sections were stained with uranyl acetate and lead citrate and photographed in a JEOL JEM 1010 electron microscope.

Statistics. Results are expressed as means \pm SD. Statistical significance was performed using an ANOVA followed by Dunnett's post hoc tests for multiple comparisons or by the unpaired two-tailed Student's $t$ test as indicated in the figure legends. A $p<0.05$ value was considered statistically significant.

\section{Results}

Tg-SREBP-2 mice exhibit brain mitochondrial cholesterol accumulation, mGSH depletion, and enhanced susceptibility to $A \boldsymbol{\beta}$ neurotoxicity

To examine whether brain mitochondrial cholesterol modulates $\mathrm{A} \beta$ toxicity we used transgenic mice overexpressing the truncated active form of the transcription factor SREBP-2 (Tg-SREBP-2), which controls cholesterol synthesis (Horton et al., 2002). We first assessed whether Tg-SREBP-2 mice displays the cholesterol accumulation in brain which has been reported in liver and adipose tissue (Horton et al., 1998). The quality of brain mitochondria from Tg-SREBP-2 mice was assessed by electron microscopy, and lack of contamination from endoplasmic reticulum, plasma membrane and endosomes was estimated from Western blot analysis of PERK, $\mathrm{Na}^{+} / \mathrm{K}^{+}$ATPase $\alpha 1$, and Rab5A, respectively (supplemental Fig. S2, available at www.jneurosci.org as supplemental material). Biochemical analyses indicated enhanced cholesterol levels in the homogenate and mitochondrial fraction of Tg-SREBP-2 mice with respect to wild-type (WT) mice (Fig. 1A). mGSH is a critical mitochondrial antioxidant, which is negatively regulated by cholesterol accumulation due to impaired transport of cytosol GSH into mitochondria via modulation of membrane dynamics (Colell et al., 1997; Marí et al., 2006). Mitochondria from Tg-SREBP-2 mice exhibited lower mGSH levels compared with wild-type mice, whereas the content of GSH in the homogenate remained unaffected (Fig. 1A). Next, we evaluated the mitochondrial response to $\mathrm{A} \beta$-mediated oxidative stress. Soluble oligomeric A $\beta 1-42(1 \mu \mathrm{M}$ for $2 \mathrm{~h})$ induced a $\sim 2$-fold higher DCF ( $2^{\prime}, 7^{\prime}$-dichlorodihydrofluorescein) fluorescence, reflecting ROS generation in mitochondria from $\mathrm{Tg}$ SREBP-2 mice compared with wild-type mice (Fig. $1 B$ ), which was accompanied by enhanced release of cytochrome $c$ and Smac/
A

\begin{tabular}{|c|c|c|c|c|}
\hline & \multicolumn{2}{|c|}{$\begin{array}{l}\text { Cholesterol, } \\
\mu \mathrm{g} / \mathrm{mg} \text { prot. }\end{array}$} & \multicolumn{2}{|c|}{$\begin{array}{c}\text { GSH, } \\
\text { nmol / mg prot. }\end{array}$} \\
\hline $\begin{array}{l}\text { WT } \\
\text { Tg }\end{array}$ & $\begin{array}{c}\text { Homo. } \\
124.0 \pm 16.1 \\
172.8 \pm 11.2^{*}\end{array}$ & $\begin{array}{c}\text { Mit. } \\
8.5 \pm 1.2 \\
16.5 \pm 4.1^{*}\end{array}$ & $\begin{array}{c}\text { Homo. } \\
28.3 \pm 4.5 \\
26.1 \pm 4.2\end{array}$ & $\begin{array}{c}\text { Mit. } \\
4.5 \pm 0.8 \\
2.3 \pm 0.6^{*}\end{array}$ \\
\hline
\end{tabular}

\section{B}

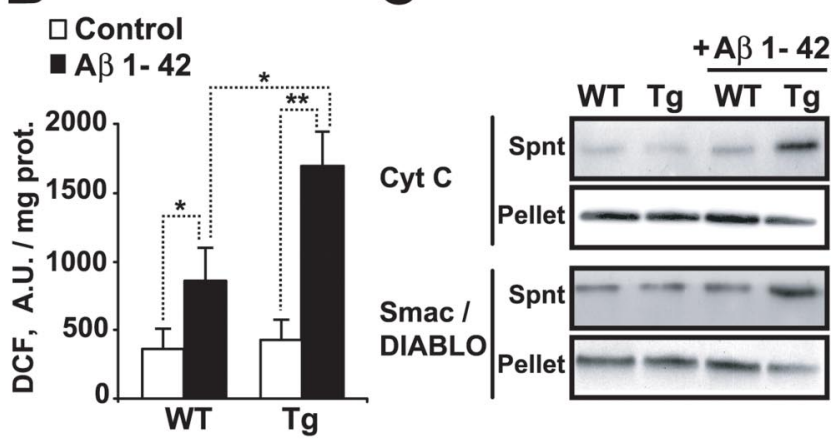

D
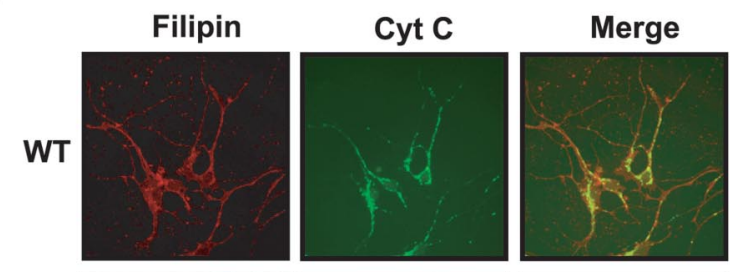

Tg
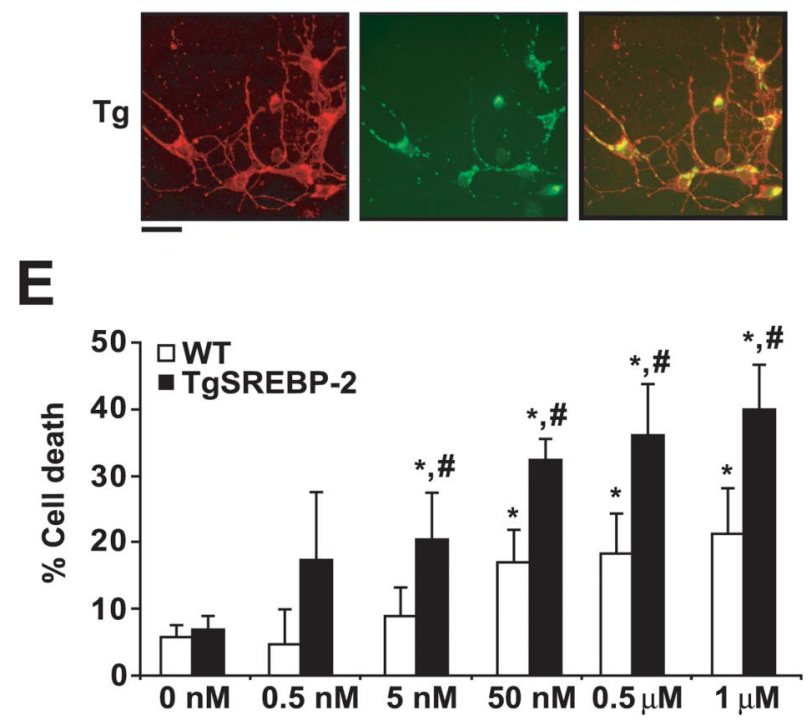

Figure 1. Increased susceptibility to $A \beta 1-42$ exposure of brain mitochondria and cortical neurons from SREBP-2 transgenic mice. $\boldsymbol{A}$, Total cholesterol levels and GSH levels of brain homogenate (Homo.) and isolated mitochondria (Mit.) from WT and SREBP-2 transgenic (Tg) mice; ${ }^{*} p<0.05$ ( $n=6-8$ per genotype). $\boldsymbol{B}, \boldsymbol{C}$, WT and transgenic (TgSREBP-2) mitochondria $(1 \mathrm{mg} / \mathrm{ml})$ were exposed to $A \beta 1-42(1 \mu \mathrm{m})$ for $2 \mathrm{~h}$. $\boldsymbol{B}$, Hydrogen peroxide generation determined by DCF fluorescence (A.U.: arbitrary units). ${ }^{*} p<0.05,{ }^{* *} p<0.01$ ( $n=6-8$ per genotype). C, After $A \beta$ treatment mitochondria were pelleted and the resulting supernatants (Spnt) and pellets were analyzed for the presence of apoptogenic proteins. Shown are representative immunoblottings of cytochrome c (Cyt C) and Smac/DIABLO $(n=4) . \boldsymbol{D}, \boldsymbol{E}$, Primary neurons isolated from WT and transgenic (TgSREBP-2) cerebral cortices at 6 DIV. $D$, Representative confocal images of cortical neurons stained with filipin (red) and mouse anti-cytochrome c antibody followed by the appropriated FITC-conjugated secondary antibody (Cyt C, green). Scale bar: $10 \mu \mathrm{m}$. $\boldsymbol{E}$, Cell death of cortical neurons after exposure to increasing doses of $A \beta 1-42$ as indicated for $48 \mathrm{~h}$. ${ }^{*} p<0.05$ versus untreated cells $(0 \mathrm{~nm})$, $\# p<0.01$ versus WT cells $(n=4-6)$. Values are mean \pm SD; mean differences were compared by unpaired Student's $t$ test. 
DIABLO (Fig. 1C). To further assess whether the increased sensitivity of isolated mitochondria to $\mathrm{A} \beta$-induced oxidative stress impacts on neuronal death, we isolated cortical neurons from wild-type and Tg-SREBP-2 embryos followed by $\mathrm{A} \beta$ exposure. Immunostaining analyses using the neuronal marker microtubule-associated protein 2 (MAP-2) confirmed the neuronal-enrichment of the cultures (supplemental Fig. S3, available at www.jneurosci.org as supplemental material). Laser confocal microscopy indicated higher cholesterol levels in cortical neurons from Tg-SREBP-2 mice compared with wild-type mice revealed by staining with filipin, a fluorescent polyene antibiotic that binds specifically to the $3 \beta$-hydroxyl group of sterols (Norman et al., 1972; Marí et al., 2006), which extensively colocalized with mitochondria stained with cytochrome $c$ antibody (Fig. $1 D$ ). These findings were accompanied by lower GSH levels in mitochondria isolated from cortical neurons of Tg-SREBP-2 mice compared with wild-type mice ( $2.1 \pm 0.4$ vs $3.3 \pm 0.5 \mathrm{nmol} / \mathrm{mg}$ protein), with the sparing of cytosol GSH content (data not shown). Finally, cortical neurons from Tg-SREBP-2 mice exhibited enhanced susceptibility to $\mathrm{A} \beta 1-42(0.5 \mathrm{nM}-1 \mu \mathrm{M}$ for $48 \mathrm{~h})$ mediated cell death compared with that of wild-type mice (Fig. $1 E$ ). Importantly, this sensitivity in Tg-SREBP-2 mice is observed at a concentration of $\mathrm{A} \beta 1-42$ as low as $5 \mathrm{nM}$.

Sensitivity of brain mitochondria from $\mathrm{NPC}^{-/-}$mice to $\mathrm{A} \beta$ induced oxidative stress and release of proapoptotic proteins

NPC1 is a late endosomal protein involved in the intracellular transport of cholesterol, whose ablation results in cholesterol and sphingolipids loading and progressive neurodegeneration (Paul et al., 2004). Recently, elevated mitochondrial cholesterol levels and mitochondrial dysfunction has been reported in the liver (Marí et al., 2006) and brain (Yu et al., 2005) from $\mathrm{NPC1}^{-1-}$ mice. Cholesterol content was higher in brain mitochondria from $\mathrm{NPC1}^{-1-}$ mice compared with wild-type mice (Fig. $2 A$ ), which was accompanied by $50-60 \%$ depletion of $\mathrm{mGSH}$ stores (Fig. $2 A$ ), without changes in cytosol GSH (data not shown). To examine the susceptibility of brain mitochondria from $\mathrm{NPC1}^{-1-}$ mice to oligomeric $A \beta$, we first determined the generation of mitochondrial ROS after exposure to $\mathrm{A} \beta 1-42(1 \mu \mathrm{M}$ for $2 \mathrm{~h})$. As seen, DCF fluorescence in response to $A \beta$ was higher in brain mitochondria from $\mathrm{NPC1}^{-1-}$ mice compared with mitochondria from $\mathrm{NPC1}^{+/+}$brain (Fig. $2 B$ ). Moreover, $A \beta$ incubation induced an enhanced release of cytochrome $c$ and Smac/DIABLO in mitochondria from $\mathrm{NPCl}^{-1-}$ mice (Fig. $2 \mathrm{C}$ ). Collectively the preceding findings in Tg-SREBP- 2 and $\mathrm{NPC}^{-1-}$ mice reveal the correlation between mitochondrial cholesterol loading and susceptibility to $\mathrm{A} \beta$-induced oxidative stress and neurotoxicity, effects that are accompanied by selective mGSH depletion.

\section{mGSH-dependent susceptibility of brain mitochondria to} A $\boldsymbol{\beta}$ toxicity

Early GSH depletion and altered GSH redox cycle have been recently shown in $\mathrm{AD}$ transgenic mice (Resende et al., 2008). Although GSH levels protect against $\mathrm{A} \beta$ neurotoxicity and $\mathrm{A} \beta$ has been shown to stimulate ROS generation from mitochondria (Cardoso et al., 2001; Boyd-Kimball et al., 2005; Lin and Beal, 2006), however, the particular role of mGSH depletion on $\mathrm{A} \beta$ mediated toxicity has not been specifically addressed before. To investigate this question, mitochondria from rat brain were depleted of GSH by ethacrynic acid (EA), which covalently binds to GSH. As shown, EA ( $5 \mu \mathrm{m}$ for $15 \mathrm{~min}$ ) depleted mGSH levels (Fig. $3 A$ ) and enhanced DCF fluorescence by $A \beta 1-42$, indicative of higher ROS generation (Fig. $3 B$ ), an effect not observed when
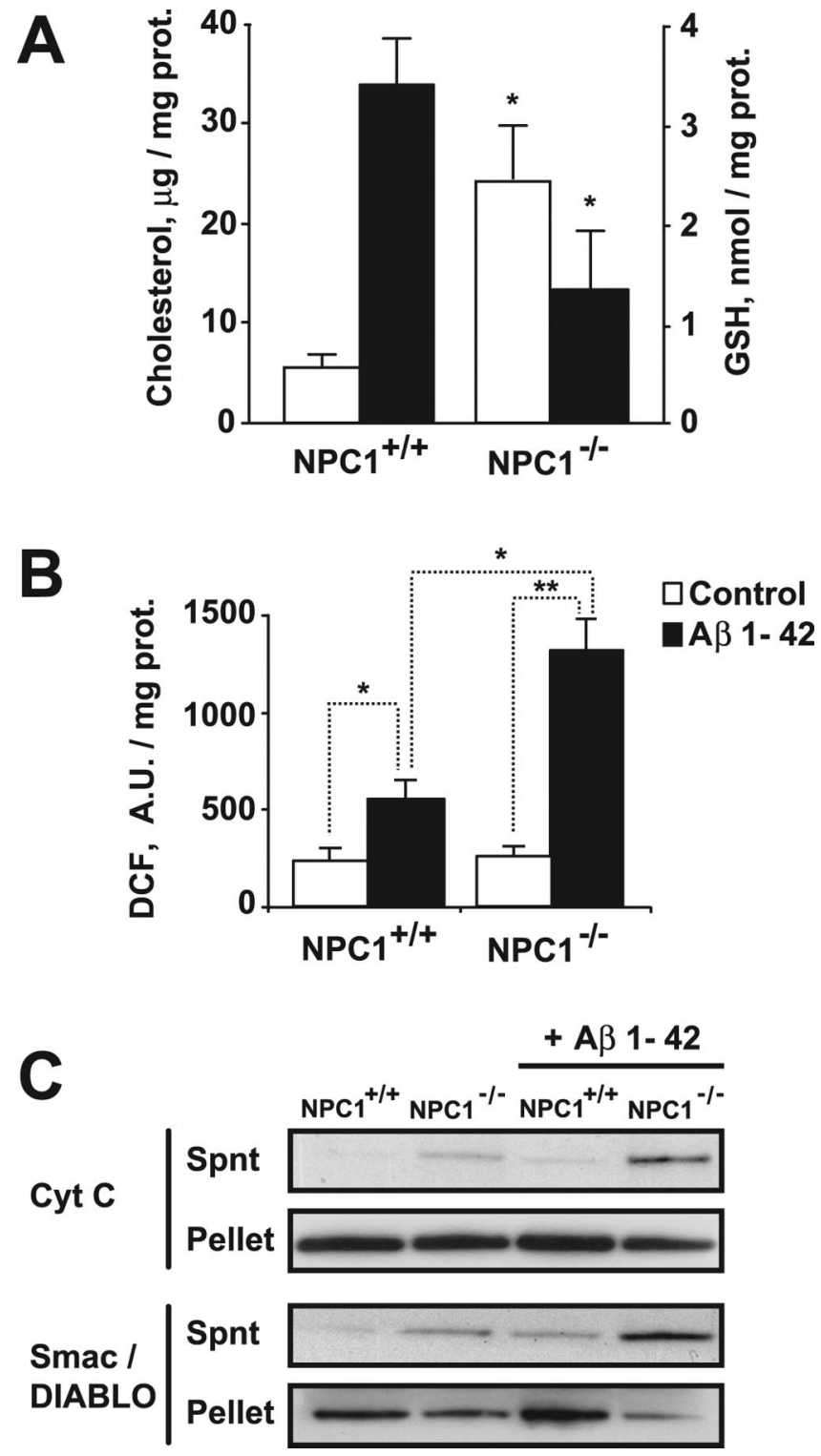

Figure 2. Isolated brain mitochondria from NPC1 knock-out mice show an increased sensitivity to A $\beta 1-42 . A$, Total cholesterol levels (white bars) and GSH levels (black bars) of isolated mitochondria from NPC1 ${ }^{+/+}$and NPC1 ${ }^{-/-}$brains. ${ }^{*} p<0.05$ ( $n=3-4$ per genotype). $\boldsymbol{B}$, Hydrogen peroxide generation determined by $D C F$ fluorescence of mitochondria $(1 \mathrm{mg} / \mathrm{ml})$ incubated with $A \beta 1-42(1 \mu \mathrm{M})$ for $2 \mathrm{~h} .{ }^{*} p<0.05,{ }^{* *} p<0.01$ ( $n=3-4$ per genotype). $C$, After $2 \mathrm{~h}$ treatment with $\mathrm{A} \beta 1-42(1 \mu \mathrm{m})$ mitochondria were pelleted and the resulting supernatants (Spnt) and pellets were analyzed by Western blotting for the presence of cytochrome $C$ $(C y t C)$ and Smac/DIABLO. Representative immunoblottings are shown. Values are mean $\pm S D$; mean differences were compared by unpaired Student's $t$ test. prot., Protein; A.U., arbitrary units.

mitochondria were exposed to the nontoxic peptide $\mathrm{A} \beta$ 42-1 (Fig. 3B). A stepwise increase in mitochondrial DCF fluorescence by A $\beta 1-42$ peptide was observed as a function of mGSH depletion by EA, that was accompanied by enhanced mitochondrial lipid peroxidation, estimated from the fluorescence loss of cisparinaric-stained mitochondria (supplemental Fig. $S 4 A-C$, available at www.jneurosci.org as supplemental material). To rule out nonspecific effects of EA, we depleted mGSH in vivo using buthionine sulfoximine (BSO), a specific inhibitor of $\gamma$-GCS ( $\gamma$-glutamylcysteine synthetase), the rate-limiting enzyme in GSH biosynthesis (Jain et al., 1991). Brain mitochondria from BSO-treated rats exhibited mGSH depletion (Fig. 3A), re- 
A

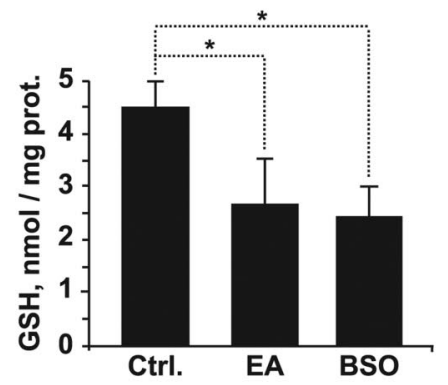

B
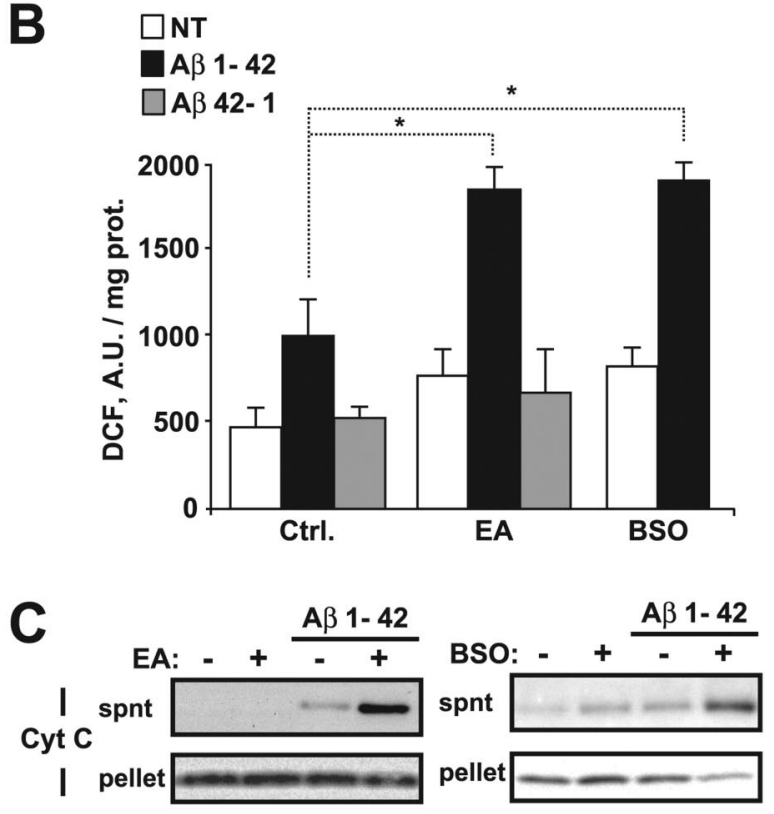

D

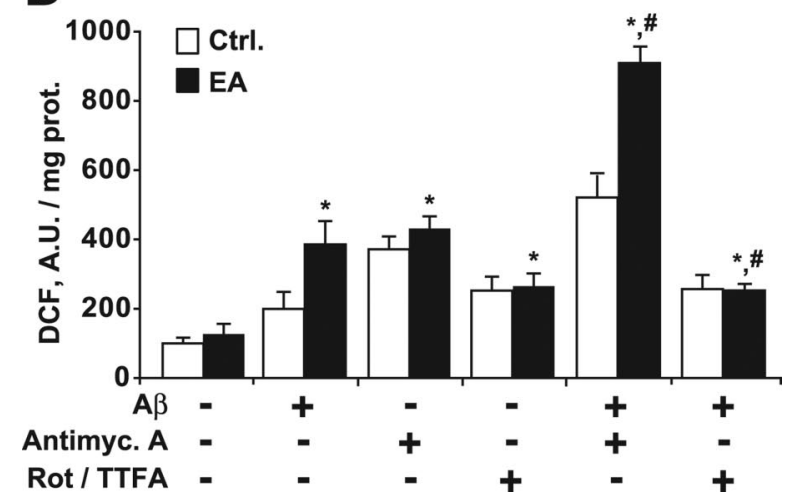

Figure 3. Mitochondrial GSH regulates $A \beta$-induced oxidative stress. Depletion of mitochondrial GSH levels was assessed in vitro by incubation of isolated mitochondria ( $1 \mathrm{mg} / \mathrm{ml})$ with 5 $\mu \mathrm{m}$ ethacrynic acid (EA) for 15 min or in vivo by inhibiting the GSH synthesis with buthionine sulfoximine treatment (BSO, $3 \mathrm{mmol} / \mathrm{kg}$ ). $A$, GSH levels after EA or BSO treatment. ${ }^{*} p<0.05$ $(n=4-6) . B, C$, Mitochondria from rat brain pretreated with EA or BSO were exposed to $A \beta$ 1-42 (5 $\mu \mathrm{m})$ or the inactive form $A \beta 42-1(5 \mu \mathrm{m})$ for $2 \mathrm{~h}$. $\boldsymbol{B}$, Hydrogen peroxide generation determined by DCF fluorescence (A.U.: arbitrary units; NT: untreated mitochondria). ${ }^{*} p<0.05$ $(n=4-6)$. C, After $A \beta$ treatment mitochondria were pelleted and the resulting supernatants (spnt) and pellets were analyzed for the presence of cytochrome $c$ (Cyt C) and Smac/DIABLO. Shown are representative immunoblottings of three independent experiments. $\boldsymbol{D}$, Effect of blocking the electron transport chain at complex I, II, or III on the generation of hydrogen peroxide by $A \beta$. After $E A$ treatment mitochondria were incubated with rotenone and TTFA (Rot/TTFA, 20 and $15 \mu \mathrm{m}$, respectively), antimycin A (Antimyc. A, $5 \mu \mathrm{m}$ ), and/or A $\beta$ (5 $\mu \mathrm{m}$ ) during $60 \mathrm{~min}$. The blockers of the respiratory complexes were added $15 \mathrm{~min}$ before exposure to $A \beta$. Hydrogen peroxide generation was assessed by $D C F$ fluorescence. ${ }^{*} p<0.05$ versus untreated mitochondria; ${ }^{\#} p<0.01$ versus $A \beta$-treated mitochondria. $(n=3)$. Values are mean \pm SD; mean differences were compared by Dunnett's test. prot., Protein; Ctrl., control. capitulating the effects observed with EA on $\mathrm{A} \beta$-induced ROS generation (Fig. $3 B$ ). In addition, mGSH depletion by both strategies enhanced the mitochondrial release of cytochrome $c$ (Fig. $3 C$ ) and Smac/DIABLO (data not shown) after exposure to $A \beta$. To further analyze the source of ROS induced by $\mathrm{A} \beta$, mitochondrial electron flow was blocked at different respiratory complexes (Fig. 3D). Inhibition of complex III by antimycin A potentiated ROS generation by $\mathrm{A} \beta$ in GSH-depleted mitochondria, while preincubation with rotenone and TTFA (thenoyltrifluoroacetone), which block complex I and II, respectively, prevented the $\mathrm{A} \beta$-mediated increase of DCF fluorescence, pointing to complex $\mathrm{III}$ as the major site of ROS generation by $\mathrm{A} \beta$. These findings indicate that $\mathrm{mGSH}$ controls the mitochondrial oxidative stress generation by $\mathrm{A} \beta$.

\section{Selective mGSH depletion with the spare of cytosol GSH} sensitizes human neuronal and glial cells to $\mathbf{A} \boldsymbol{\beta}$ neurotoxicity We next asked whether selective mGSH depletion modulates $\mathrm{A} \beta$ neurotoxicity. To address this question, human neuroblastoma SH-SY5Y cells were exposed to 3-hydroxy-4-pentenoate (HP), a fatty acid derivative which is biotransformed in mitochondria into a Michael electrophile and then conjugated with GSH, resulting in its depletion (Marí et al., 2006, 2008, García-Ruiz et al., 2003). As seen, HP decreased mGSH levels with the sparing of GSH cytosol stores (Fig. 4A), sensitizing SH-SY5Y cells to A $\beta$ induced cell death (Fig. 4B). Similar results were observed in glial-derived H4, C6 and U118 cell lines after selective mGSH depletion by HP and $\mathrm{A} \beta$ challenge (supplemental Fig. S5 $A, B$, available at www.jneurosci.org as supplemental material), indicating that the role of $\mathrm{mGSH}$ in regulating $\mathrm{A} \beta$ cytotoxicity is not restricted to neuronal cells. mGSH depletion in SH-SY6Y cells by HP potentiated $\mathrm{A} \beta$-induced DCF fluorescence, indicative of enhanced ROS generation, and loss of mitochondrial membrane potential (supplemental Fig. S6 $A, B$, available at www.jneurosci. org as supplemental material). Dying SH-SY5Y cells after HP plus $\mathrm{A} \beta$ exposure exhibited apoptotic features, including chromatin condensation/nuclear fragmentation (Fig. 4C) and increased caspase-3 activity (Fig. 4D). Interestingly, preincubation with the pancaspase inhibitor qVD-OPH (quinoline-Val-Asp-CH2difluorophenoxy) prevented the morphological changes in chromatin condensation (Fig. 4C) and caspase-3 activation (Fig. 4D) induced by HP plus $\mathrm{A} \beta$ challenge, but failed to protect against cell death (Fig. $4 E$ ). Pretreatment with antioxidants such as $N$-acetylcysteine (NAC) and butylated hydroxyanisole (BHA) significantly decreased ROS generation induced by HP plus $\mathrm{A} \beta$ exposure (Fig. $4 F$ ) and the combined pretreatment with NAC and qVD-OPH protected mGSH-depleted SH-SY5Y cells against cell death triggered by $\mathrm{A} \beta$ (Fig. $4 E$ ). Overall, these findings indicate that selective mGSH depletion sensitizes neuronal and glial cells to $\mathrm{A} \beta$ by stimulating oxidant-dependent cell death and caspaseindependent apoptosis.

\section{Neuroinflammation in Tg-SREBP-2 mice after in vivo infusion of human $\mathrm{A} \boldsymbol{\beta}$}

Having shown that brain mitochondrial cholesterol modulates $\mathrm{A} \beta$ toxicity by regulating mGSH, we next evaluated the onset of pathological features of $\mathrm{AD}$ such as neuroinflammation after intracerebroventricular infusion of human $\mathrm{A} \beta 1-42$ in $\mathrm{Tg}$ SREBP-2 mice. Staining with an antibody that recognizes human $\mathrm{A} \beta$ (but not the endogenous mouse $\mathrm{A} \beta$ ) demonstrated diffuse amyloid deposition in the hippocampus of $\mathrm{A} \beta$-infused mice (for 28 d) (Fig. 5A). Quantitative determination by ELISA revealed equivalent $\mathrm{A} \beta$ loading in wild-type mice and Tg-SREBP- 2 mice 

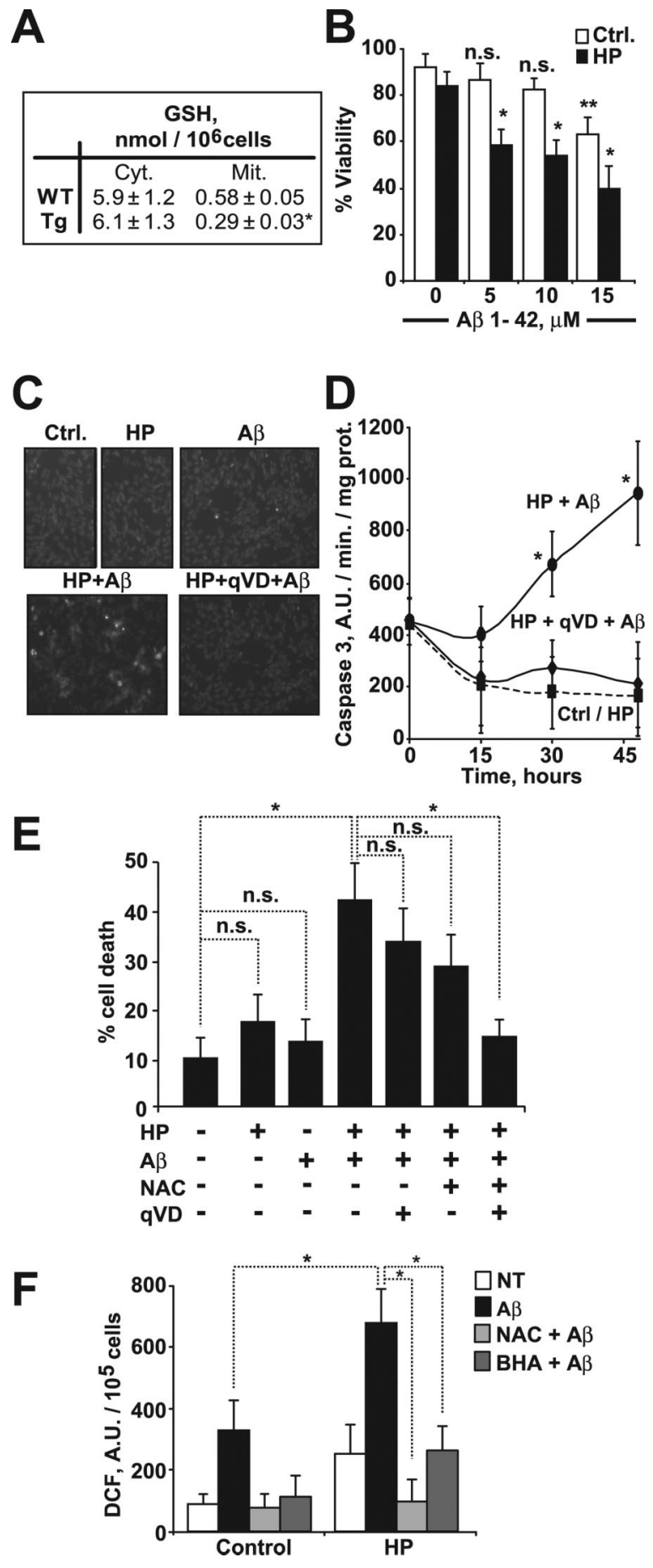

Figure 4. Selective depletion of mitochondrial GSH in human neuroblastoma SH-SY5Y cells enhances the apoptotic cell death induced by A $\beta$. Mitochondrial GSH depletion was assessed by incubating cells with (S)-3-hydroxy-4-pentenoate (HP, $5 \mathrm{~mm}$ ) for 10 min. A, GSH levels. ${ }^{*} p=0.002$ ( $n=$ 4). Cyt., Cytosol; Mit., mitochondria. $\boldsymbol{B}$, Cell viability after $24 \mathrm{~h}$ incubation with increasing concentrations of A $\beta 1-42 .{ }^{*} p<0.01$ versus HP-treated cells at $0 \mu \mathrm{m},{ }^{* *} p=0.02$ versus control (Ctrl.) cells at $0 \mu \mathrm{m} ; \mathrm{n} . \mathrm{s}$. not significant $(n=4)$. C, Chromatin morphology of cells exposed to A $\beta 1-42(5 \mu \mathrm{m}, 24 \mathrm{~h})$ analyzed by Hoechst-33258 staining. Original magnification, $200 \times(n=4)$. D. Caspase-3 activity of cell extracts from cells exposed to $A \beta 1-42(5 \mu \mathrm{m}, 24 \mathrm{~h})$ with or without the pancaspase inhibitor qVD-0PH $(20 \mu \mathrm{m})$. ${ }^{*} p<0.05$ versus HP-treated cells. $(n=3)$. $\boldsymbol{E}, \boldsymbol{F}$, After preincubation with the antioxidant agents $\mathrm{N}$-acetyl-cysteine (NAC, $3 \mathrm{~mm}$ ) or butylated hydroxyanisole (BHA, $20 \mu \mathrm{m}$ ) and/or the caspase inhibitor qVD-OPH $(20 \mu \mathrm{m})$ for $2 \mathrm{~h}$, mitochondrial GSH was depleted by HP treatment and cells were exposed to $A \beta 1-42(5 \mu \mathrm{M})$. ( $(n=3-4)$. $\boldsymbol{E}$, Cell death analyzed by PI staining at $24 \mathrm{~h}$ exposure to $A \beta 1-42 .{ }^{*} p<0.01$. $\boldsymbol{F}$, Hydrogen peroxide generation after $2 \mathrm{~h}$ incubation with $A \beta 1-$ 42. ${ }^{*} p<0.05$ (A.U.: arbitrary units). Values are mean \pm SD; mean differences were compared by Dunnett's test $(\boldsymbol{B}, \boldsymbol{E}$, and $\boldsymbol{F})$ or unpaired Student's $t$ test.
$(54.2 \pm 14.6$ and $66 \pm 11.2 \mathrm{nmol} / \mathrm{mg}$ protein, respectively). Moreover, confocal analysis showed a significant colocalization of $\mathrm{A} \beta$ with cytochrome $c$ staining (Fig. $5 B$ ), indicating that a fraction of the infused $A \beta$ targeted mitochondria. Of note, endogenous brain A $\beta 1-42$ levels were similar in WT and Tg-SREBP-2 mice (supplemental Fig. S7, available at www.jneurosci.org as supplemental material).

Neuroinflammation, manifested as activated microglia and astrocytes close to $A \beta$ depositions, is an invariant characteristic of $\mathrm{AD}$ brain, which plays a key role in the progression of the disease by further amplifying $A \beta$ generation and neuronal damage (Heneka and O'Banion, 2007). Greater microglia activation, determined by F4/80 immunostaining, was observed in the hippocampus of Tg-SREBP- 2 mice infused with $\mathrm{A} \beta$ compared with vehicle-infused or $\mathrm{A} \beta$-infused wild-type mice (Fig. $5 C$ ). Astrocyte activation, manifested as GFAP immunoreactivity, was also elevated in hippocampal regions of $\mathrm{A} \beta$-infused Tg-SREBP-2 mice (Fig. $5 C$ ). Moreover, confocal analysis of $\mathrm{A} \beta$-infused $\mathrm{Tg}$ SREBP-2 brains revealed the presence of microglia and astrocytes colocalizing with $A \beta$ in amyloid deposits (supplemental Fig. S8, available at www.jneurosci.org as supplemental material). These histological analyses were complemented by quantitative measurements of mRNA levels of proinflammatory cytokines such as TNF- $\alpha$ and IL- $1 \beta$. Increased expression of TNF- $\alpha$ and IL- $1 \beta$ was only observed in Tg-SREBP-2 brains infused with $\mathrm{A} \beta$ (Fig. $5 D$ ). Thus, Tg-SREBP- 2 mice are more susceptible to $A \beta$-induced neuroinflammation.

Increased oxidative stress, synaptodendritic degeneration and neuronal damage in Tg-SREBP-2 mice after $\mathrm{A} \beta$ infusion We next assessed the susceptibility of Tg-SREBP-2 mice to A $\beta$ induced oxidative stress and neurodegeneration. Malondialdehyde (MDA), an end product of lipid peroxidation, and accumulation of oxidized proteins assessed by carbonyl protein immunoblotting were significantly higher in the brain of $A \beta$ infused Tg-SREBP-2 mice compared with $\mathrm{A} \beta$-infused wild-type mice, with no signs of oxidative stress detected in brains of vehicle-infused wild-type or Tg-SREBP-2 mice (Fig. 6A, $B$ ). Previous studies have shown that synaptic injury is an early event in the progression of $\mathrm{AD}$, which correlates with the severity of cognitive deficits in AD patients (Masliah et al., 1994). As shown, the levels of the presynaptic protein synaptophysin were significantly lower in Tg-SREBP-2 mice infused with A $\beta$ compared with wildtype mice or vehicle-infused brains (Fig. $6 C$ ), indicating extensive synaptic loss. In addition, neuronal death and apoptosis estimated by Fluoro-Jade B-positive degenerating neurons and TUNEL staining, respectively, were higher in Tg-SREBP-2 mice after intracerebroventricular $A \beta$ infusion compared with wildtype mice (Fig. $6 D, E$ ). These data underscore the susceptibility of Tg-SREBP-2 mice to $\mathrm{A} \beta$-induced neurodegeneration.

\section{GSH ethyl ester coinfusion restores $\mathrm{mGSH}$ and protects} against $\mathrm{A} \beta$-induced neurodegeneration in Tg-SREBP-2 mice To address whether the exacerbated inflammation and neuronal death of Tg-SREBP-2 mice after $A \beta$ infusion is promoted by cholesterol-mediated mGSH depletion, GSH ethyl ester (GSHee), a membrane-permeable form of GSH, was coinfused with $A \beta$. GSHee significantly increased the mitochondrial pool of GSH in Tg-SREBP- 2 mice $(3.2 \pm 0.2$ vs $1.4 \pm 0.5 \mathrm{nmol} / \mathrm{mg}$ protein), preventing $\mathrm{A} \beta$-induced increase in MDA levels (Fig. $6 F$ ) and protein oxidation estimated by carbonyl protein immunoreactivity (supplemental Fig. S9A, available at www.jneurosci.org as supplemental material). Moreover, reactive astrogliosis and 
A

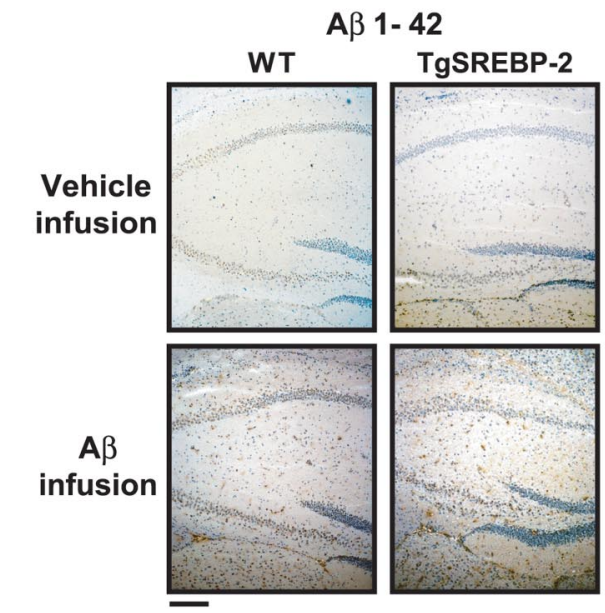

B
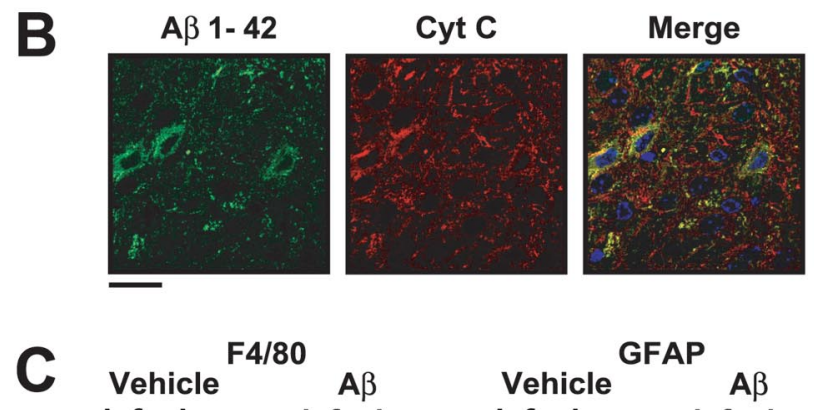

$F 4 / 80$

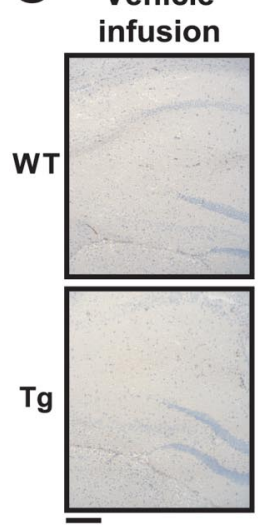

$A \beta$
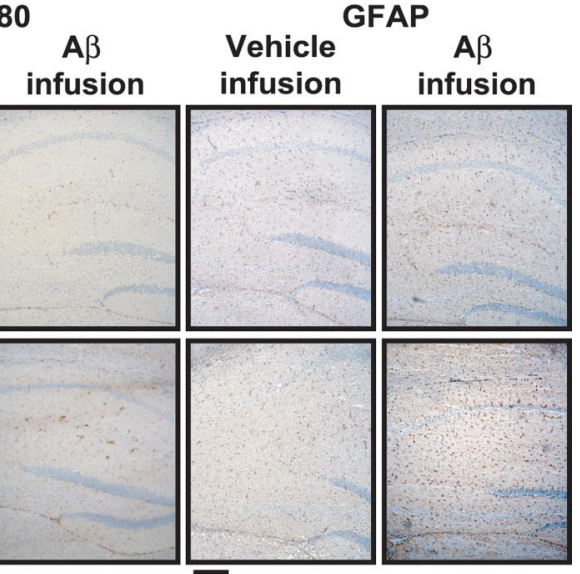

D TNF
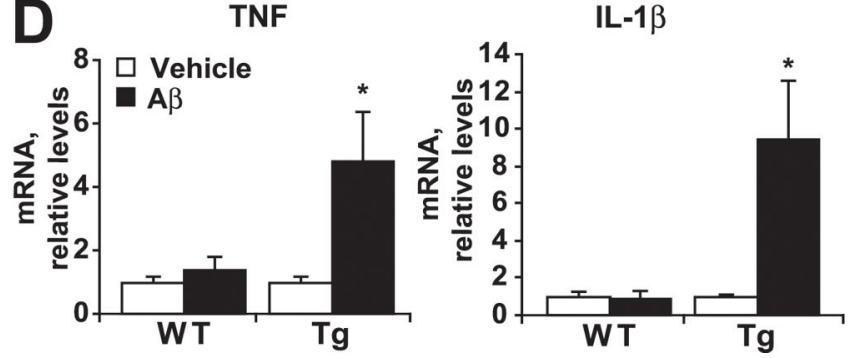

IL-1 $\beta$

Figure 5. Increased neuroinflammation in SREBP-2 transgenic mice after A $\beta 1-42$ infusion. WT and SREBP-2 transgenic (TgSREBP-2) mice were subjected to continuous intracerebroventricular infusion of vehicle or human $A \beta 1-42$ solution $(1.2 \mu \mathrm{g} / \mathrm{d})$ for $28 \mathrm{~d}$; then, half of the brain was processed for immunohistochemistry and the other hemisphere used for biochemical analysis. $n=6-8$ mice per group. $A, A \beta 1-42$ immunohistochemical staining. Representative photomicrographs of hippocampus from WT and transgenic mice after infusion are shown. Scale bar: $100 \mu \mathrm{m}$. $\boldsymbol{B}$, Confocal analysis of $A \beta$ internalization. Shown are representative images of $A \beta 1-24$ (green) and cytochrome $c$ (red) immunofluorescence from hippocampal sections of TgSREBP-2 brains after the infusion period. Merged image indicates partial colocalization of $A \beta$ with the mitochondrial marker cytochrome c (Cyt C, yellow). Nuclei were stained with Hoechst33258 (shown only in merged image; blue). Scale bar: $10 \mu \mathrm{m}$. C, Activation of microglia and microgliosis, determined by GFAP and F4/80 immunoreactivity, respectively, were also reduced in Tg-SREBP- 2 mice when GSHee was coinfused with $A \beta$ (supplemental Fig. S9B, available at www.jneurosci.org as supplemental material). This outcome correlated with a significant decrease in the mRNA expression of the proinflammatory cytokines TNF- $\alpha$ and IL-1 $\beta$ (Fig. $6 G$ ). In addition, neuronal damage, assessed by Fluoro-Jade $B$ staining and TUNEL assay, in the hippocampal regions of $\mathrm{A} \beta$-infused $\mathrm{Tg}$ SREBP-2 brains was prevented by GSHee coinfusion (Fig. $6 D, E$ ). We further analyzed whether intraperitoneal administration of GSHee was therapeutic against $A \beta$-induced neuroinflammation and neuronal loss. As seen, intraperitoneal GSHee administration during the $\mathrm{A} \beta$ infusion period significantly increased $\mathrm{mGSH}$ content (Fig. 7A), attenuating MDA levels (Fig. 7B) and carbonyl protein immunoblotting (Fig. $7 C$ ), indicative of oxidative stress induced by $\mathrm{A} \beta$ in Tg-SREBP- 2 mice. In addition, the enhanced presence of reactive astrocytes (Fig. $7 D$ ) and the upregulated expression of TNF- $\alpha$ (Fig. $7 E$ ) observed in $\mathrm{A} \beta$-infused transgenic mice were significantly prevented by GSHee therapy, which correlates with a significant decrease in neuronal damage (Fig. $7 F$ ). Thus, these data indicate that strategies that boost mGSH such as GSHee protect against $\mathrm{A} \beta$-induced neurodegeneration.

\section{Enhanced mitochondrial cholesterol loading and mGSH depletion in APP/PS1 transgenic mice}

To address the relevance of the preceding findings in $\mathrm{AD}$, we examined the mitochondrial cholesterol and GSH content in a genetic mouse model of AD, namely, APP/PS1 transgenic mice. Brain mitochondria were isolated from 4-, 7-, and 10-month-old APP/PS1 transgenic mice. As seen (Fig. 8A), mitochondrial cholesterol levels were unchanged in 4- and 7-month-old transgenic mice, increasing twice as much in 10-month-old APP/PS1 transgenic mice compared with wild-type mice of the same age. As expected from our findings in Tg-SREBP- 2 and $\mathrm{NPC1}^{-1-}$ mice, the mGSH levels decreased only in 10-month-old APP/PS1 transgenic mice (Fig. 8B). Preceding the mitochondrial cholesterol loading and the subsequent mGSH depletion, we observed a significant generation of $\mathrm{A} \beta$ detected by ELISA in 4-month-old APP/PS1 mice (data not shown). Furthermore, either SREBP-2 mRNA and protein levels were significantly elevated in Tg-APP/ PS1 mice (Fig. 8C,D), indicating that activation of SREBP-2 may contribute to the increase in cholesterol content. Thus, these findings lend further support for the relevance of enhanced mitochondrial cholesterol levels in $\mathrm{AD}$.

\section{Discussion}

Epidemiological, genetic and biochemical studies have identified cholesterol, $\mathrm{A} \beta$ and mitochondria as key factors in $\mathrm{AD}$ pathogenesis, but the specific relationship of this triad has not been addressed before. In particular, the role of cholesterol in AD examined thus far has been limited to the amyloidogenic processing of APP at the plasma membrane to generate $A \beta$. In this regard, varying proportions of the presenilins and other components of the $\gamma$-secretase complex (nicastrin, Aph-1 and Pen-2), along with

$\leftarrow$

astrocytes analyzed by F4/80 and GFAP immunostaining, respectively. Shown are representative photomicrographs of F4/80 and GFAP immunoreactivity as indicated, in sections of hippocampus from infused WT and SREBP-2 transgenic (Tg) mice. Scale bar: $100 \mu \mathrm{m}$. D, TNF- $\alpha$ and IL- $1 \beta$ mRNA expression analyzed by real-time PCR from WT and SREBP-2 transgenic (Tg) brain after vehicle or $A \beta$ infusion. Shown are relative values after normalization against $18 \mathrm{~s}$ expression and are representative of three experiments $\pm S D,{ }^{*} p<0.01$ versus vehicleinfused TgSREBP-2 mice. Mean differences were compared by unpaired Student's $t$ test. 
A
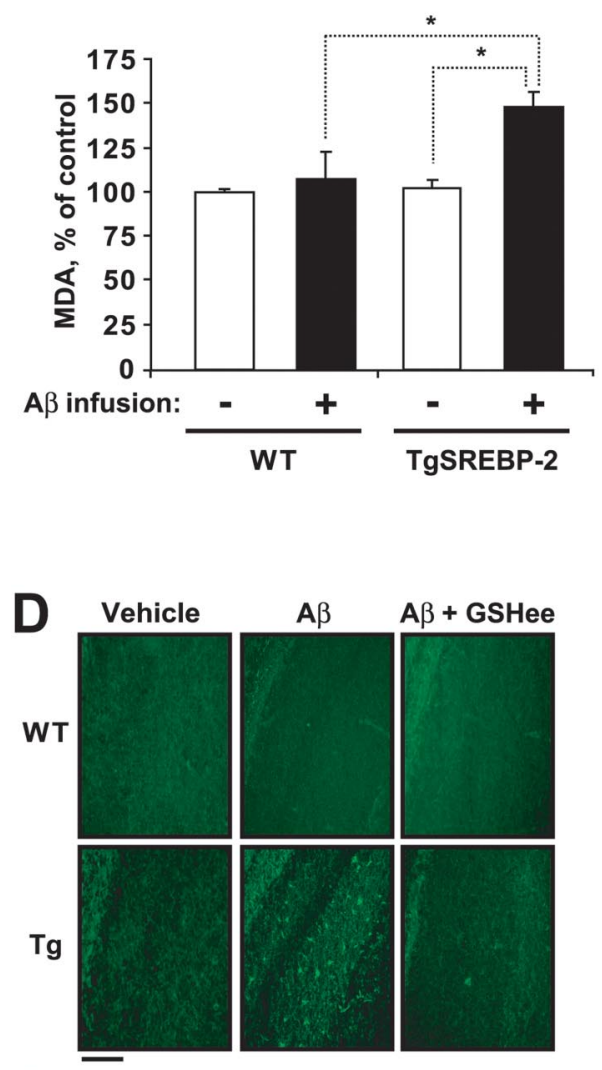

$\mathbf{F}$

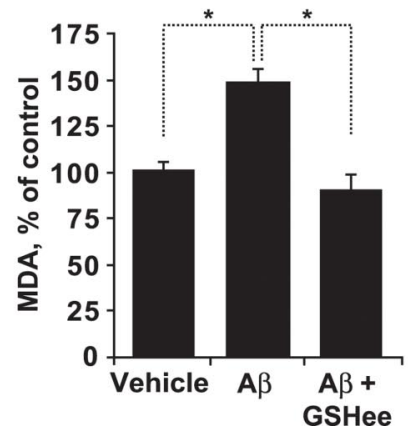

B
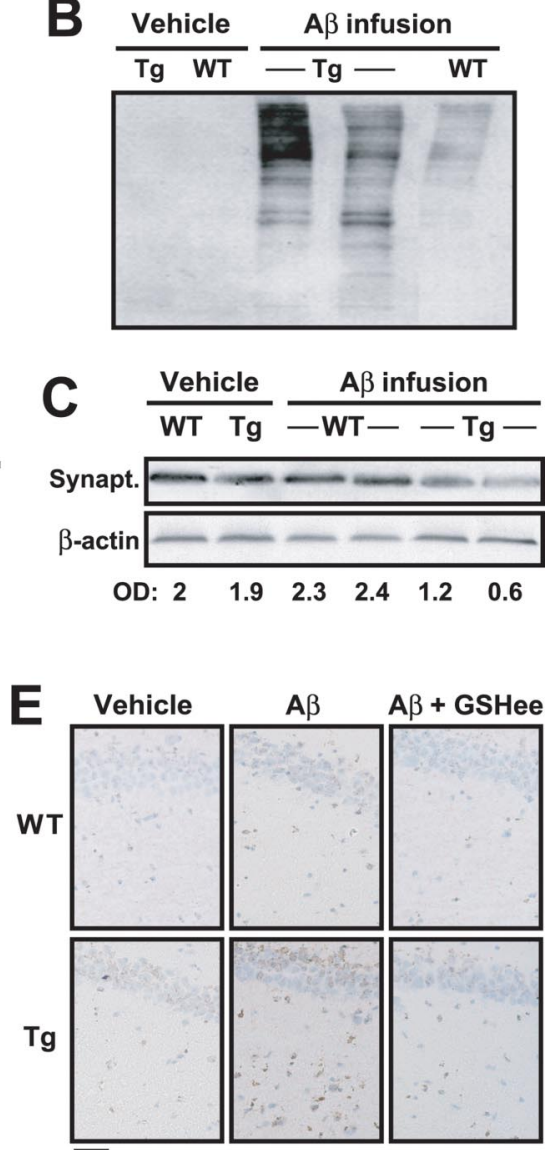

$G$

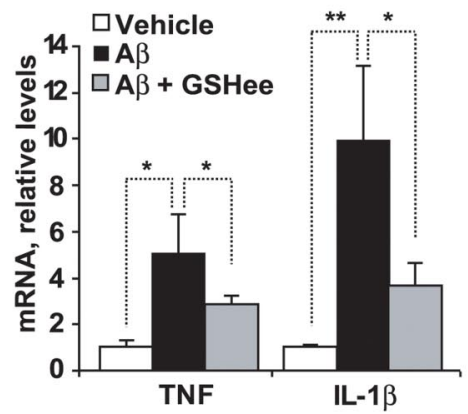

Figure 6. $\quad \mathrm{A} \beta$-infused TgSREBP-2 mice display enhanced oxidative stress and neuronal damage which is prevented by GSH ethyl ester (GSHee) coinfusion. WT and TgSREBP-2 mice were subjected to continuous infusion of vehicle or human A $\beta 1-42$ solution $(1.2 \mu \mathrm{g} / \mathrm{d})$ for $28 \mathrm{~d}$. $n=6-8$ mice per group. $A$, Lipid peroxidation estimated as production of malondialdehyde (MDA). ${ }^{*} p<0.03$. B Representative immunoblotting showing presence of carbonyl proteins in WT and TgSREBP-2 (Tg) brains after infusion. C, Representative immunoblotting showing synaptophysin (Synapt.) protein levels after infusion. Densitometric values of the bands representing synaptophysin immunoreactivity were normalized with the values of the corresponding $\beta$-actin bands (0.D.: normalized optical density). D, Representative images of degenerated neurons in hippocampal regions by Fluoro-Jade $B$ staining. Scale bar: $50 \mu \mathrm{m}$. $\boldsymbol{E}$, Representative images of apoptotic cells in hippocampus by terminal deoxynucleotidyl transferasemediated nick-end labeling. Scale bar: $25 \mu \mathrm{m}$. $\boldsymbol{F}$, Lipid peroxidation in infused TgSREBP-2 brains estimated as malondialdehyde levels (MDA). ${ }^{*} p<0.01(n=6)$. G, TNF- $\alpha$ and IL-1 $\beta$ mRNA expression analyzed by real-time PCR from infused TgSREBP-2 brains. Relative values were normalized against 18 s expression. ${ }^{*} p<0.05,{ }^{* *} p<0.01(n=6)$. Values are mean \pm SD; mean differences were compared by unpaired Student's $t$ test.

$\gamma$-secretase activity and the $\beta$-secretase BACE1, are present in detergent-resistant cholesterol-enriched lipid rafts (Taylor and Hooper, 2007). In addition, the activities of BACE1 and $\gamma$-secretase are stimulated by rafts lipid components, such as glycosphingolipids and cholesterol (Kalvodova et al., 2005; Ariga et al., 2008; Osenkowski et al., 2008). Intriguingly, although the presence of APP in detergent-resistant rafts is relatively minor
(Lee et al., 1998), once localized to the raft, the APP may be rapidly cleaved by $\beta$ - and $\gamma$-secretases, thus contributing to $\mathrm{A} \beta$ generation. Moreover, previous studies have shown that cholesteryl-ester levels directly correlate with $\mathrm{A} \beta$ production (Puglielli et al., 2001) and that statins inhibit the dimerization of $\beta$-secretase via both isoprenoid- and cholesterol-mediated mechanisms (Parsons et al., 2006).

In the current study, we examined the role of cholesterol in $\mathrm{AD}$ from an unusual perspective and provide evidence linking mitochondrial cholesterol to $\mathrm{A} \beta$ neurotoxicity, consistent with and expanding the recognized role of mitochondrial dysfunction in AD (Casley et al., 2002; Lustbader et al., 2004; Caspersen et al., 2005; Lin and Beal, 2006; Manczak et al., 2006). In addition to being targets of $A \beta$ toxicity, it is conceivable that mitochondria may constitute an additional source of $A \beta$ generation, in agreement with the presence of APP in mitochondria from AD-vulnerable brain regions (Devi et al., 2006), and the finding of functional complexes of APP with $\gamma$-secretase and IDE in mitochondria (Hansson et al., 2004; Leissring et al., 2004), arguing that these organelles may contribute to the amyloidogenic APP processing and hence $A \beta$ generation. Regardless of the source of $A \beta$ generation either via the more established pathway of APP processing at the plasma membrane, particularly in cholesterol-enriched domains, or its in situ generation in mitochondria, we provide evidence that mitochondrial cholesterol accumulation stands as a critical determinant of $\mathrm{A} \beta$ toxicity both in vitro and in vivo using Tg-SREBP-2 and $\mathrm{NPCl}^{-1-}$ mice.

It has been described that SREBP-2 downregulates the expression of genes which control brain $\mathrm{A} \beta$ clearance, such as LDLR-related protein 1 (also known as LRP) (Deane et al., 2004). Moreover, recent studies in $\mathrm{AD}$ patients and two mouse models of AD show that overexpression of serum response factor and myocardin in cerebral vascular smooth muscle cells (VSMC) generates an $A \beta$ nonclearing VSMC phenotype through transactivation of SREBP-2, which is associated with $A \beta$ accumulation (Bell et al., 2009); thus, it is conceivable that Tg-SREBP-2 may exhibit increased brain $\mathrm{A} \beta$ content secondary to lower LRP1 expression. Although we did not examine the expression level of LRP1, we did observe that the content of endogenous $\mathrm{A} \beta$ was similar in WT and Tg-SREBP-2 mice. These unexpected findings are consistent with evidence indicating that LRP1 promotes APP endocytosis and its processing to $\mathrm{A} \beta$ production (Ulery et al., 2000; Zerbinatti et al., 2004).

In agreement with the downregulation of mGSH by increased 
cholesterol-mediated impairment of mGSH transport from cytosol (Marí et al., 2006, 2008; Colell et al., 1997), we observed that isolated mitochondria from both Tg-SREBP-2 mice and NPC1 knockout mice exhibit mGSH depletion and enhanced susceptibility to $\mathrm{A} \beta$-mediated toxicity and mitochondrial membrane permeabilization. Although GSH exists in both cytosol and mitochondria, this latter pool has been shown to control the susceptibility to stimuli that trigger mitochondrial oxidative stress including TNF, Fas or hypoxia (Marí et al., 2006, 2008; Colell et al., 1997; Lluis et al., 2007). However, although total GSH depletion and altered GSH redox cycle has been described in AD, the particular pool of $\mathrm{mGSH}$ in modulating $\mathrm{A} \beta$ toxicity has not been specifically addressed. Two lines of evidence indicate that the mGSH depletion specifically accounted for the increased susceptibility to $\mathrm{A} \beta$ observed in these genetic models. First, the sensitivity of rat brain mitochondria to $\mathrm{A} \beta$-mediated oxidative stress and release of intermembrane apoptotic proteins was dependent on the levels of mGSH. Second, selective pharmacological depletion of mGSH with the spare of cytosol GSH in human neuroblastoma and glial cells sensitized to $\mathrm{A} \beta$-mediated cell death. Hence these findings expand the role of cholesterol in $\mathrm{A} \beta$ neurotoxicity, indicating that in addition to fostering the amyloidogenic processing of APP, mitochondrial cholesterol modulates $\mathrm{A} \beta$ neurotoxicity via $\mathrm{mGSH}$ regulation. Interestingly, recent findings have shown that hydrogen peroxide promotes $\mathrm{A} \beta$ production through JNK-dependent activation of $\gamma$-secretase (Shen et al., 2008), implying that in addition to the modulation of $\mathrm{A} \beta$ toxicity, enhanced mitochondrial cholesterolmediated mGSH depletion may activate an autoamplification loop by stimulating oxidative stress to further generate $\mathrm{A} \beta$, thus establishing a toxic vicious cycle.

Although increased cholesterol levels have been described in membranes from brain tissue samples of AD patients (Cutler et al., 2004; Bandaru et al., 2007), the specific pool of mitochondrial cholesterol has not been previously reported to the best of our knowledge. However, enhanced immunocytochemical localization of steroidegenic acute regulatory protein (StAR) has been described in the pyramidal hippocampal neurons of AD-affected patients (Webber et al., 2006). Given the role of StAR in the mitochondrial transport of cholesterol (Soccio and Breslow, 2004) and hence in the modulation of mitochondrial cholesterol levels (Montero et al., 2008), the increased expression of StAR in AD patients, would strongly suggest that mitochondrial cholesterol accumulation may actually occur in patients with AD. Indeed, in the current study, we observed mitochondrial cholesterol loading and subsequent $\mathrm{mGSH}$ depletion in APP/PS1 transgenic mice, a genetic
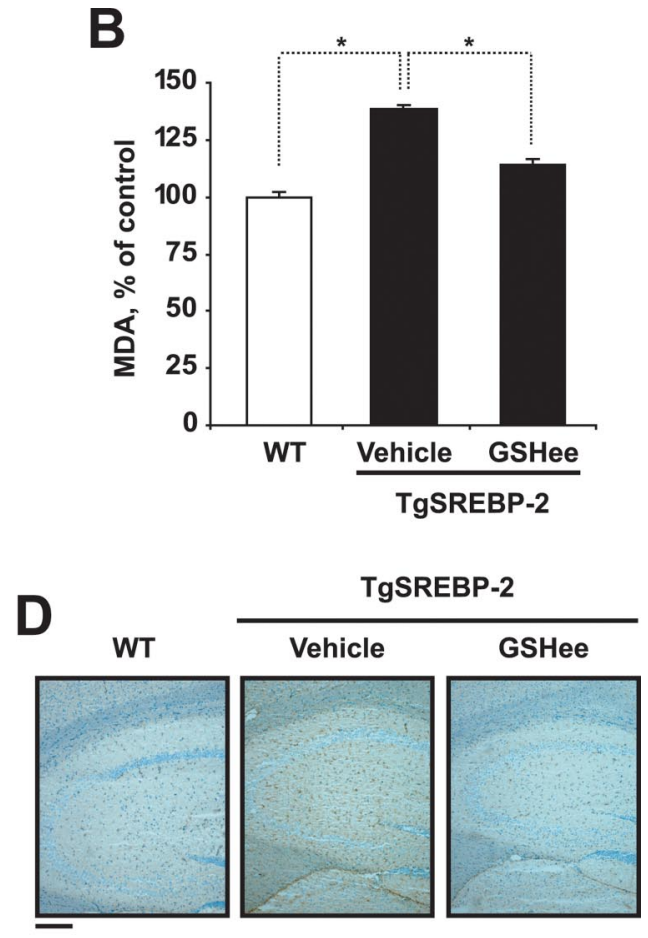

$\mathbf{F}$

TgSREBP-2

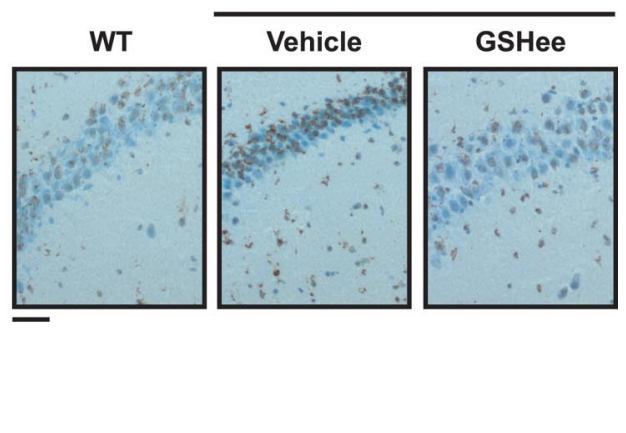

Figure 7. GSH ethyl ester (GSHee) intraperitoneal therapy protects against $A \beta$-induced neurodegeneration in Tg-SREBP-2 mice. WT and TgSREBP-2 mice were subjected to continuous infusion of human A $\beta 1-42$ solution ( $1.2 \mu \mathrm{g} / \mathrm{d})$ for $28 \mathrm{~d}$. GSH ethyl ester $(1.25 \mathrm{mmol} / \mathrm{kg} / \mathrm{d})$ or vehicle alone were administered intraperitoneally over the last 2 week of the infusion period. $n=4-6$ cytes analyzed by GFAP immunostaining. Shown are representative photomicrographs GFAP immunoreactivity in hippocampal ${ }^{*} p<0.05 . \boldsymbol{F}$, Representative images of apoptotic cells in hippocampus by terminal deoxynucleotidyl transferase-mediated nick-end labeling. Scale bar: $25 \mu \mathrm{m}$. Values are mean \pm SD; mean differences were compared by unpaired Student's $t$ test.

mouse model of $\mathrm{AD}$, and interestingly, these changes in mitochondria were preceded by $\mathrm{A} \beta$ accumulation in the brain of APP/ PS1 mice. Based on this temporal relationship, it is tempting to speculate that $\mathrm{A} \beta$ may regulate cholesterol homeostasis and/or trafficking. Although this needs to be specifically addressed, consistent with this possibility, previous studies underscored that $\mathrm{A} \beta$ 1-40/1-42 ratio altered lipid homeostasis, and that familial presenilin mutations decreased the $\mathrm{A} \beta 1-40 / 1-42$ ratio resulting in enhanced cholesterol levels (Grimm et al., 2005), suggesting that $\mathrm{A} \beta$ generation contributed to increased cholesterol content. A complication in this possible scenario of mutual regulation between cholesterol and $A \beta$ is the observation that cholesterylesters unlike free cholesterol modulated $\mathrm{A} \beta$ generation (Puglielli et al., 2001). 


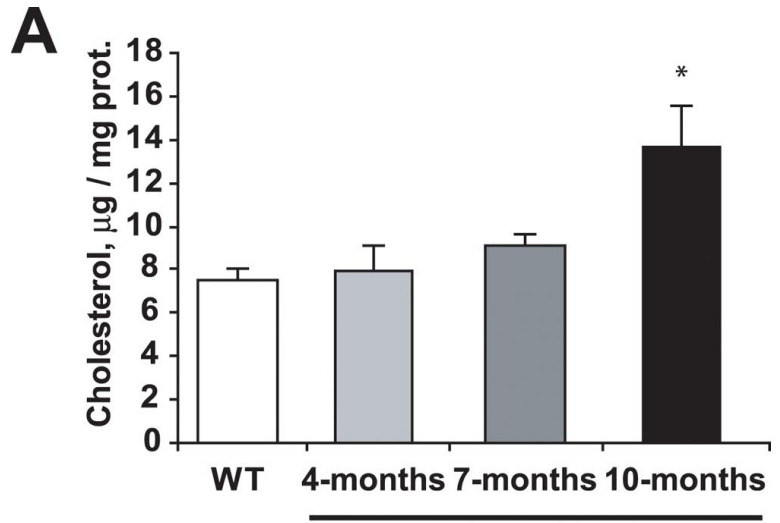

Tg-APP/PS1
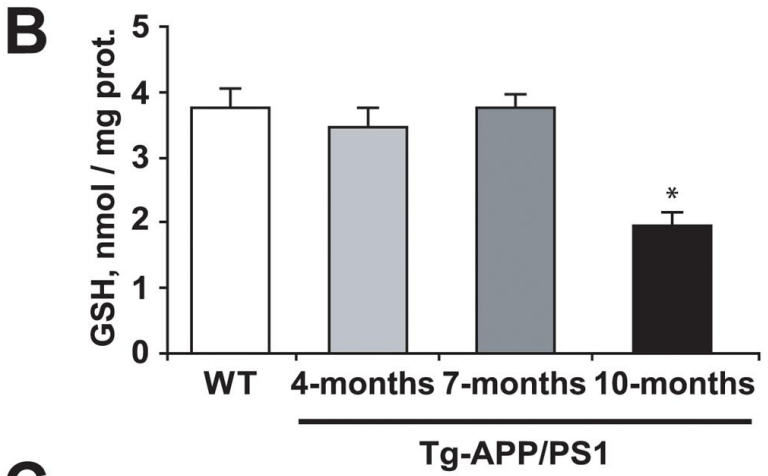

C

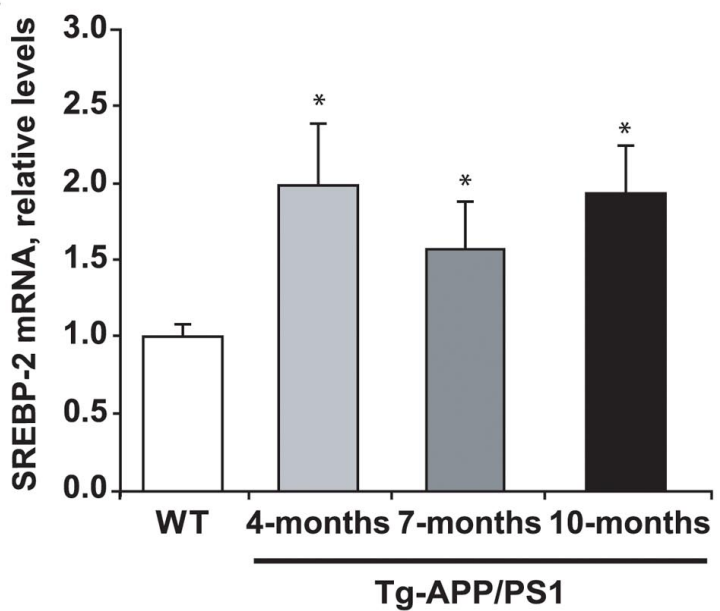

D

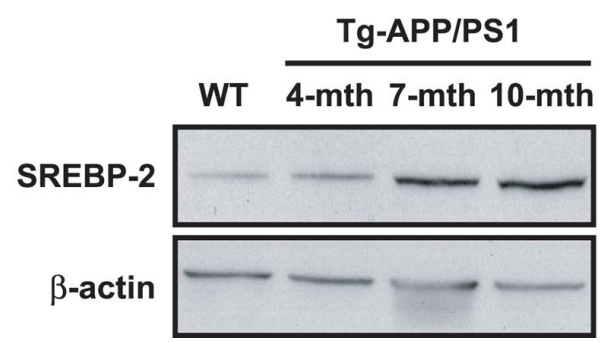

Figure 8. Brain mitochondria from 10-month-old AD transgenic mice exhibit increased cholesterol and depleted GSH levels. $\boldsymbol{A}$, Total cholesterol levels. $\boldsymbol{B}$, GSH levels of isolated brain mitochondria from WT mice and AD transgenic mice (Tg-APP/PS1) at the indicated ages. ${ }^{*} p<$ $0.05(n=3-4)$. C, D, SREBP-2 expression in brain extracts from WT mice and Tg-APP/PS1 transgenic mice at the indicated ages. $C$, SREBP-2 mRNA expression analyzed by real-time PCR. Relative values were normalized against 18 s expression. ${ }^{*} p<0.05(n=3-4)$. D, Representative immunoblotting showing SREBP-2 protein levels. $\beta$-Actin levels were analyzed as a loading control. Values are mean \pm SD; mean differences were compared by unpaired Student's $t$ test. prot., Protein.
Previous studies described the requirement for functional mitochondria in $A \beta$-mediated neurotoxicity and that $A \beta$ interacts with the regulatory heme of complex IV leading to mitochondrial dysfunction and ROS production (Cardoso et al., 2001; Atamna and Boyle, 2006). Through inhibition of electron flow at different mitochondrial respiratory complexes, we show that complex III is a major site for mitochondrial ROS by $\mathrm{A} \beta$, whose levels increased if $\mathrm{mGSH}$ levels are low, resulting in mitochondrial depolarization, release of cytochrome $c$, and caspase- 3 activation. Interestingly caspase inhibition failed to protect mGSH-dependent sensitization of SH-SY5Y cells to A $\beta$-mediated cell death despite efficiently preventing the acquisition of apoptotic features, suggesting that $\mathrm{A} \beta$ stimulated both an oxidant-dependent cell death pathway and caspase-independent apoptosis pathways, which are modulated by mGSH levels.

Our in vivo studies underscore a higher sensitivity of $\mathrm{Tg}$ SREBP-2 mice to infusion of human $A \beta$, resulting in enhanced lipid peroxidation, oxidative modification of proteins, glia activation, indicative of neuroinflammation, and neuronal damage. Although cholesterol upregulation in Tg-SREBP-2 did not modulate endogenous $A \beta$ generation, we observed that a significant fraction of infused human $\mathrm{A} \beta$ colocalized with mitochondria, pointing to the mitochondria as a target of the $\mathrm{A} \beta$ toxicity in vivo. To substantiate that the increased susceptibility of Tg-SREBP-2 mice to in vivo $\mathrm{A} \beta$ infusion was mediated by mitochondrial cholesterol-induced mGSH depletion, we tested the role of coinfusing A $\beta$ with GSH ethyl ester. GSH ethyl ester is a membrane permeable form of GSH, which unlike GSH precursors such as $N$-acetylcysteine increases mGSH independently of the transport of GSH into mitochondria (Marí et al., 2006, 2008). This implies that GSH ethyl ester bypasses the block of cytosol GSH transport into mitochondria imposed by cholesterol-mediated membrane dynamics, thus leading to mGSH replenishment (Marí et al., 2006, 2008; Colell et al., 1997). The downregulation of oxidative stress, neuroinflammation and protection against in vivo infusion of $\mathrm{A} \beta$ in Tg-SREBP-2 via mGSH recovery highlights the relevance of mitochondrial cholesterol-mediated regulation of $\mathrm{mGSH}$ in $\mathrm{A} \beta$-induced neurodegeneration. From a therapeutical perspective, the fact that the particular pool of $\mathrm{mGSH}$ rather than cytosol GSH determines $A \beta$ susceptibility implies that efforts should focus to specifically replenish $\mathrm{mGSH}$ to slow down disease progression. The therapeutic usefulness of this strategy is illustrated here by the ability of intraperitoneal administration of GSH ethyl ester in protecting against $\mathrm{A} \beta$-induced neuroinflammation and neuronal loss. In addition to directly modulating mGSH by GSH ethyl ester, targeting the increased pool of mitochondrial cholesterol may be of relevance in $\mathrm{AD}$, as it would be expected to restore mGSH levels. In line with this possibility, it was shown in obese ob/ob mice that atorvastatin therapy was useful in preventing susceptibility to TNF-mediated steatohepatitis by preventing mitochondrial cholesterol loading which subsequently resulted in increased mGSH levels (Marí et al., 2006). Taking this precedent as well as the previous suggestions for the use of statins in AD (Wolozin et al., 2000; Fassbender et al., 2001; Parsons et al., 2006), the therapeutic combination of statins plus GSH ethyl ester may be of potential therapeutic significance in AD.

\section{References}

Anstey KJ, Lipnicki DM, Low LF (2008) Cholesterol as a risk factor for dementia and cognitive decline: a systematic review of prospective studies with meta-analysis. Am J Geriatr Psychiatry 16:343-354.

Ariga T, McDonald MP, Yu RK (2008) Role of ganglioside metabolism in 
the pathogenesis of Alzheimer's disease-a review. J Lipid Res 49:1157-1175.

Atamna H, Boyle K (2006) Amyloid-beta peptide binds with heme to form a peroxidase: relationship to the cytopathologies of Alzheimer's disease. Proc Natl Acad Sci U S A 103:3381-3386.

Bandaru VV, Troncoso J, Wheeler D, Pletnikova O, Wang J, Conant K, Haughey NJ (2007) ApoE4 disrupts sterol and sphingolipid metabolism in Alzheimer's but not normal brain. Neurobiol Aging. Advance online publication. Retrieved May 4, 2009. doi:10.1016/j.neurobiolaging. 2007.07.024.

Bell RD, Deane R, Chow N, Long X, Sagare A, Singh I, Streb JW, Guo H, Rubio A, Van Nostrand W, Miano JM, Zlokovic BV (2009) SRF and myocardin regulate LRP-mediated amyloid-beta clearance in brain vascular cells. Nat Cell Biol 11:143-153.

Boyd-Kimball D, Sultana R, Abdul HM, Butterfield DA (2005) Gammaglutamylcysteine ethyl ester-induced up-regulation of glutathione protects neurons against Abeta(1-42)-mediated oxidative stress and neurotoxicity: implications for Alzheimer's disease. J Neurosci Res 79:700-706.

Cardoso SM, Santos S, Swerdlow RH, Oliveira CR (2001) Functional mitochondria are required for amyloid beta-mediated neurotoxicity. FASEB J 15:1439-1441.

Casley CS, Canevari L, Land JM, Clark JB, Sharpe MA (2002) Beta-amyloid inhibits integrated mitochondrial respiration and key enzyme activities. J Neurochem 80:91-100.

Caspersen C, Wang N, Yao J, Sosunov A, Chen X, Lustbader JW, Xu HW, Stern D, McKhann G, Yan SD (2005) Mitochondrial Abeta: a potential focal point for neuronal metabolic dysfunction in Alzheimer's disease. FASEB J 19:2040-2041.

Colell A, García-Ruiz C, Morales A, Ballesta A, Ookhtens M, Rodés J, Kaplowitz N, Fernández-Checa JC (1997) Transport of reduced glutathione in hepatic mitochondria and mitoplasts from ethanol-treated rats: effect of membrane physical properties and S-adenosyl-L-methionine. Hepatology 26:699-708.

Cutler RG, Kelly J, Storie K, Pedersen WA, Tammara A, Hatanpaa K, Troncoso JC, Mattson MP (2004) Involvement of oxidative stress-induced abnormalities in ceramide and cholesterol metabolism in brain aging and Alzheimer's disease. Proc Natl Acad Sci U S A 101:2070-2075.

Deane R, Zlokovic BV (2007) Role of blood brain barrier in the pathogenesis of Alzheimer's disease. Curr Alzheimer Res 4:191-197.

Deane R, Wu Z, Sagare A, Davis J, Du Yan S, Hamm K, Xu F, Parisi M, LaRue B, Hu HW, Spijkers P, Guo H, Song X, Lenting PJ, Van Nostrand WE, Zlokovic BV (2004) LRP/amyloid beta-peptide interaction mediates differential brain efflux of Abeta isoforms. Neuron 43:333-344.

Devi L, Prabhu BM, Galati DF, Avadhani NG, Anandatheerthavarada HK (2006) Accumulation of amyloid precursor protein in the mitochondrial import channels of human Alzheimer's disease brain is associated with mitochondrial dysfunction. J Neurosci 26:9057-9068.

Fassbender K, Simons M, Bergmann C, Stroick M, Lutjohann D, Keller P, Runz H, Kuhl S, Bertsch T, von Bergmann K, Hennerici M, Beyreuther K, Hartmann T (2001) Simvastatin strongly reduces levels of Alzheimer's disease $\beta$-amyloid peptides $A \beta 42$ and $A \beta 40$ in vitro and in vivo. Proc Natl Acad Sci U S A 98:5856-5861.

Fernandez-Checa JC, Kaplowitz N (2005) Hepatic mitochondrial glutathione: transport and role in disease and toxicity. Toxicol Appl Pharmacol 204:263-273.

Fernandez-Checa JC, Ookhtens M, Kaplowitz N (1987) Effect of chronic ethanol feeding on rat hepatocytic glutathione: compartmentation, efflux and response to incubation with ethanol. J Clin Invest 80:57-62.

Frautschy SA, Yang F, Calderón L, Cole GM (1996) Rodent models of Alzheimer's disease: rat $\mathrm{A} \beta$ infusion approaches to amyloid deposits. Neurobiol Aging 17:311-321.

García-Ruiz C, Colell A, Marí M, Morales A, Calvo M, Enrich C, FernándezCheca JC (2003) Defective TNF-alpha-mediated hepatocellular apoptosis and liver damage in acidic sphingomyelinase knockout mice. J Clin Invest 111:197-208.

Grimm MO, Grimm HS, Pätzold AJ, Zinser EG, Halonen R, Duering M, Tschäpe JA, De Strooper B, Müller U, Shen J, Hartmann T (2005) Regulation of cholesterol and sphingomyelin metabolism by amyloid beta and presenilin. Nat Cell Biol 7:1118-1123.

Haass C, Selkoe DJ (2007) Soluble protein oligomers in neurodegeneration: lessons from the Alzheimer's amyloid beta-peptide. Nat Rev Mol Cell Biol 8:101-112.
Hansson CA, Frykman S, Farmery MR, Tjernberg LO, Nilsberth C, Pursglove SE, Ito A, Winblad B, Cowburn RF, Thyberg J, Ankarcrona M (2004) Nicastrin, presenilin, APH-1, and PEN-2 form active gamma-secretase complexes in mitochondria. J Biol Chem 279:51654-51660.

Heneka MT, O'Banion MK (2007) Inflammatory processes in Alzheimer's disease. J Neuroimmunol 184:69-91.

Horton JD, Shimomura I, Brown MS, Hammer RE, Goldstein JL, Shimano H (1998) Activation of cholesterol synthesis in preference to fatty acid synthesis in liver and adipose tissue of transgenic mice overproducing sterol regulatory element-binding protein-2. J Clin Invest 101:2331-2339.

Horton JD, Goldstein JL, Brown MS (2002) SREBPs: activators of the complete program of cholesterol and fatty acid synthesis in the liver. J Clin Invest 109:1125-1131.

Hsiao K, Chapman P, Nilsen S, Eckman C, Harigaya Y, Younkin S, Yang F, Cole G (1996) Correlative memory deficits, Abeta elevation, and amyloid plaques in transgenic mice. Science 274:99-102.

Jain A, Mårtensson J, Stole E, Auld PA, Meister A (1991) Glutathione deficiency leads to mitochondrial damage in brain. Proc Natl Acad Sci U S A 88:1913-1917.

Kalvodova L, Kahya N, Schwille P, Ehehalt R, Verkade P, Drechsel D, Simons K (2005) Lipids as modulators of proteolytic activity of BACE: involvement of cholesterol, glycosphingolipids, and anionic phospholipids in vitro. J Biol Chem 280:36815-36823.

Lee SJ, Liyanage U, Bickel PE, Xia W, Lansbury PT Jr, Kosik KS (1998) A detergent-insoluble membrane compartment contains $A \beta$ in vivo. Nat Med 4:730-734.

Leissring MA, Farris W, Wu X, Christodoulou DC, Haigis MC, Guarente L, Selkoe DJ (2004) Alternative translation initiation generates a novel isoform of insulin-degrading enzyme targeted to mitochondria. Biochem J 383:439-446.

Lin MT, Beal MF (2006) Mitochondrial dysfunction and oxidative stress in neurodegenerative diseases. Nature 443:787-795.

Lluis JM, Buricchi F, Chiarugi P, Morales A, Fernandez-Checa JC (2007) Dual role of mitochondrial reactive oxygen species in hypoxia signaling: activation of nuclear factor-\{kappa $\}$ B via c-SRC and oxidant-dependent cell death. Cancer Res 67:7368-7377.

Lustbader JW, Cirilli M, Lin C, Xu HW, Takuma K, Wang N, Caspersen C, Chen X, Pollak S, Chaney M, Trinchese F, Liu S, Gunn-Moore F, Lue LF, Walker DG, Kuppusamy P, Zewier ZL, Arancio O, Stern D, Yan SS, et al. (2004) ABAD directly links Abeta to mitochondrial toxicity in Alzheimer's disease. Science 304:448-452.

Manczak M, Anekonda TS, Henson E, Park BS, Quinn J, Reddy PH (2006) Mitochondria are a direct site of A $\{$ beta $\}$ accumulation in Alzheimer's disease neurons: implications for free radical generation and oxidative damage in disease progression. Hum Mol Genet 15:1437-1449.

Marí M, Caballero F, Colell A, Morales A, Caballeria J, Fernandez A, Enrich C, Fernandez-Checa JC, García-Ruiz C (2006) Mitochondrial free cholesterol loading sensitizes to TNF- and Fas-mediated steatohepatitis. Cell Metab 4:185-198.

Marí M, Colell A, Morales A, Caballero F, Moles A, Fernández A, Terrones O, Basañez G, Antonsson B, García-Ruiz C, Fernández-Checa JC (2008) Mechanism of mitochondrial glutathione-dependent hepatocellular susceptibility to TNF despite NF-kB activation. Gastroenterology 134:1507-1520.

Mårtensson J, Han J, Griffith OW, Meister A (1993) Glutathione ester delays the onset of scurvy in ascorbate-deficient guinea pigs. Proc Natl Acad Sci U S A 90:317-321.

Masliah E, Mallory M, Hansen L, DeTeresa R, Alford M, Terry R (1994) Synaptic and neuritic alterations during the progression of Alzheimer's disease. Neurosci Lett 174:67-72.

Mattson MP (2004) Pathways towards and away from Alzheimer's disease. Nature 430:631-639.

Montero J, Morales A, Llacuna L, Lluis JM, Terrones O, Basañez G, Antonsson B, Prieto J, García-Ruiz C, Colell A, Fernández-Checa JC (2008) Mitochondrial cholesterol contributes to chemotherapy resistance in hepatocellular carcinoma. Cancer Res 68:5246-5256.

Norman AW, Demel RA, de Kruyff B, van Deenen LL (1972) Studies on the biological properties of polyene antibiotics. Evidence for the direct interaction of filipin with cholesterol. J Biol Chem 247:1918-1929.

Notkola IL, Sulkava R, Pekkanen J, Erkinjuntti T, Ehnholm C, Kivinen P, Tuomilehto J, Nissinen A (1998) Serum total cholesterol, apolipoprotein E 4 allele, and Alzheimer's disease. Neuroepidemiology 17:14-20. 
Oddo S, Caccamo A, Shepherd JD, Murphy MP, Golde TE, Kayed R, Metherate R, Mattson MP, Akbari Y, LaFerla FM (2003) Triple-transgenic model of Alzheimer's disease with plaques and tangles:intracellular Abeta and synaptic dysfunction. Neuron 39:409-421.

Osenkowski P, Ye W, Wang R, Wolfe MS, Selkoe DJ (2008) Direct and potent regulation of gamma-secretase by its lipid microenvironment. J Biol Chem 283:22529-22540.

Parsons RB, Price GC, Farrant JK, Subramaniam D, Adeagbo-Sheikh J, Austen BM (2006) Statins inhibit the dimerization of b-secretase via both isoprenoid and cholesterol-mediated mechanisms. Biochem J 399:205-214.

Paul CA, Boegle AK, Maue RA (2004) Before the loss: neuronal dysfunction in Niemann-Pick Type C disease. Biochim Biophys Acta 1685:63-76.

Pirttilä T, Soininen H, Mehta PD, Heinonen O, Lehtimäki T, Bogdanovic N, Paljärvi L, Kim KS, Kosunen O, Winblad B, Riekkinen P Sr, Wisniewski HM (1997) Apolipoprotein E genotype and amyloid load in Alzheimer disease and control brains. Neurobiol Aging 18:121-127.

Puglielli L, Konopka G, Pack-Chung E, MacKenzie Ingano LA, Berezovska O, Hyman BT, Chang TY, Tanzi RE, Kovacs DM (2001) Acyl-coenzyme A:cholesterol acyltransferase modulates the generation of the amyloid b-peptide. Nat Cell Biol 3:905-912.

Resende R, Moreira PI, Proença T, Deshpande A, Busciglio J, Pereira C, Oliveira CR (2008) Brain oxidative stress in a triple-transgenic mouse model of Alzheimer disease. Free Radic Biol Med 44:2051-2057.

Schönknecht P, Lütjohann D, Pantel J, Bardenheuer H, Hartmann T, von Bergmann K, Beyreuther K, Schröder J (2002) Cerebrospinal fluid 24Shydroxycholesterol is increased in patients with Alzheimer's disease compared to healthy controls. Neurosci Lett 324:83-85.

Selkoe DJ (2007) Developing preventive therapies for chronic diseases: lessons learned from Alzheimer's disease. Nutr Rev 65:S239-243.

Shankar GM, Li S, Mehta TH, Garcia-Munoz A, Shepardson NE, Smith I, Brett FM, Farrell MA, Rowan MJ, Lemere CA, Regan CM, Walsh DM, Sabatini BL, Selkoe DJ (2008) Amyloid-beta protein dimers isolated directly from Alzheimer's brains impair synaptic plasticity and memory. Nat Med 14:837-842.

Shen C, Chen Y, Liu H, Zhang K, Zhang T, Lin A, Jing N (2008) Hydrogen peroxide promotes $\mathrm{A} \beta$ production through JNK-dependent activation of g-secretase. J Biol Chem 283:17721-17730.
Soccio RE, Breslow JL (2004) Intracellular cholesterol transport. Arterioscler Thromb Vasc Biol 24:1150-1160.

Tanzi RE, Moir RD, Wagner SL (2004) Clearance of Alzheimer's Ab peptide: The many roads to perdition. Neuron 43:605-608.

Taylor DR, Hooper NM (2007) Role of lipid rafts in the processing of the pathogenic prion and Alzheimer's amyloid-beta proteins. Semin Cell Dev Biol 18:638-648

Tietze F (1969) Enzymatic method for quantitative determination of nanogram amounts of total and oxidized glutathione: applications to mammalian blood and other tissues. Anal Biochem 27:502-522.

Ulery PG, Beers J, Mikhailenko I, Tanzi RE, Rebeck GW, Hyman BT, Strickland DK (2000) Modulation of beta-amyloid precursor protein processing by the low density lipoprotein receptor-related protein (LRP). Evidence that LRP contributes to the pathogenesis of Alzheimer's disease. J Biol Chem 275:7410-7415.

Walsh DM, Selkoe DJ (2004) Deciphering the molecular basis of memory failure in Alzheimer's disease. Neuron 44:181-193.

Webber KM, Stocco DM, Casadesus G, Bowen RL, Atwood CS, Previll LA Harris PL, Zhu X, Perry G, Smith MA (2006) Steroidogenic acute regulatory protein (StAR): evidence of gonadotropin-induced steroidogenesis in Alzheimer disease. Mol Neurodegener 1:14.

Wolozin B, Kellman W, Ruosseau P, Celesia GG, Siegel G (2000) Decreased prevalence of Alzheimer disease associated with 3-hydroxy-3-methyglutaryl coenzyme A reductase inhibitors. Arch Neurol 57:1439-1443.

Yu W, Gong JS, Ko M, Garver WS, Yanagisawa K, Michikawa M (2005) Altered cholesterol metabolism in Niemann-Pick type C1 mouse brains affects mitochondrial function. J Biol Chem 280:11731-11739.

Zeevalk GD, Manzino L, Sonsalla PK, Bernard LP (2007) Characterization of intracellular elevation of glutathione (GSH) with glutathione monoethyl ester and GSH in brain and neuronal cultures: relevance to Parkinson's disease. Exp Neurol 203:512-520.

Zerbinatti CV, Wozniak DF, Cirrito J, Cam JA, Osaka H, Bales KR, Zhuo M, Paul SM, Holtzman DM, Bu G (2004) Increased soluble amyloid-beta peptide and memory deficits in amyloid model mice overexpressing the low-density lipoprotein receptor-related protein. Proc Natl Acad Sci U S A 101:1075-1080.

Zlokovic BV (2005) Neurovascular mechanisms of Alzheimer's neurodegeneration. Trends Neurosci 28:202-208. 